\title{
INCLUSIVE PACKAGING RECYCLING SYSTEMS: IMPROVING SUSTAINABLE WASTE MANAGEMENT FOR A CIRCULAR ECONOMY
}

\author{
Jacqueline E. Rutkowski *
}

University of Leeds Faculty of Business - Economic Division, Maurice Keyworth Building Leeds LS99JT, United Kingdom SUSTENTAR Institute for Studies and Research on Sustainability - Research, Avenida Hum 2863, Jangada Casa Branca Brumadinho Minas Gerais 35460-000, Brazil

Article Info:
Received:
16 July 2020
Revised:
2 October 2020
Accepted:
15 October 2020
Available online:
28 December 2020
Keywords:
Waste Picker
Extended Producer Responsibility
Plastic recycling
Circular Economy
Sustainable Integrated WM
Packaging

\section{INTRODUCTION}

Waste is an important element of pollution of soil, groundwater and marine waters to which approximately $5 \%$ of global greenhouse gas ( $\mathrm{GHG}$ ) emissions are attributed. As a result of a linear economic model based on infinite growth, around 2 billion tons of solid waste are generated annually in the world and this generation is expected to increase by $70 \%$ until 2050 (Silpa et al. 2018). Waste recycling, as a part of Integrated Sustainable Waste Management (ISWM) (Wilson, Vellis and Rodic 2013), can reduce the scarcity of natural resources caused by the linear economy (Ellen Macarthur Foundation 2013) and the consequent negative environmental impacts of the growing global trash production. Expanding the extent and depth of waste recycling is a key to building a more circular economy (CE), contributing to the global climate change effort, at local and national scales (Ellen Macarthur Foundation 2013a). Moreover, implementing solid waste management in cities around the world is considered essential for meeting some of the United Nations' Sustainable Development Goals (Lenkiewicz 2016).

The realization of ISWM around the world, however, requires the identification of accessible solutions, especially in low and middle income countries (LMIC), where this policy is hardly implemented due to financial and governance restrictions (Hoornweg and Bhada- Tata 2012; Scheinberg, Wilson and Rodic 2010). In LMIC packaging represents about 20 to $30 \%$ of urban waste; in wealthy countries packaging accounts half of the urban waste generated (OECD 2001; OECD 2016). Therefore, reducing the amount of packaging waste that ends up in a landfill is a common target in many countries to increase the recovery of natural resources and save energy (Lifset, Atasu, Tojo 2013; Gupt and Sahay 2015). Reducing waste packaging has been identified also as a pivotal way of controlling marine plastic litter (Ellen Macarthur Foundation 2013a). Measures of Extended Responsibility to the Packaging Producer (P-EPR) 
have been introduced in many countries to achieve these goals since the 1990s (GiZ 2018; OECD 2016). About 100 P-EPR initiatives are in course in the world, most of them in richer countries but also in LMIC as Brazil, India, China and some African countries (IRR 2018, Demajorovic et al. 2014).

In many LMIC, packaging recycling is being carried out by waste pickers (WP) who have developed a low-cost and labour-intensive approach to waste collection and recycling services, which results in more waste recovery, reduces operational costs of waste management (WM) and turns waste into a means of poverty alleviation for a few million people (Wilson, Velis, Cheeseman 2006; Medina, 2007; Gutberlet, 2008; Scheinberg, Simpson, Gupt 2010; Sembiring \& Nitivattananon 2010; Wilson, Rodic, Scheinberg 2012; Ezeah et al. 2013; Rutkowski and Rutkowski, 2015). Consequently, some tools e.g. InteRa (Velis et al, 2012) and value chain analysis (Jaligot et al, 2016) have been developed to promote the integration of WP at WM and many international agencies have recommended drawing lessons from WP initiatives to guide the development of WM policies(OECD, 2016; World Bank, 2008; UN-Habitat, 2010). However, these initiatives are poorly understood by WM policymakers and operators, who raise some negative aspects, real or perceived, associated with them (Gupt and Sahay 2015).

This paper aims to address the question of how these informal operators should be invited to work with, rather than against, the formal WM to reach ISWM and make cities more sustainable and inclusive. The Brazilian experience in P-EPR (BR P-EPR), where WP have been historically recognized as a player of the $W M$, is investigated using the EU experience in P-EPR (EU P-EPR), the first and the most consolidated experience in the world, as the benchmark. Quantitative and qualitative methods were combined to discuss how the two models could learn from each other to expand the effective recovery of MSW resources, improving the CE. An inclusive P-EPR scheme is proposed, which consists of the integration of the WP and their mode of operation in the WM in order to incorporate the respective economic, social and environmental benefits of that social technology developed by them. The advantages and challenges for the dissemination of this scheme to other LMICs are also highlighted.

\section{MATERIAL AND METHODS}

The comparative case study focused on the P-EPR because packaging is responsible for 30 to $50 \%$ of municipal waste, and EPR has been a policy implemented in many countries to address this problem (Hwang 2007; OECD 2016).

Initially, a systematic literature review was carried out to record the way in which P-EPR schemes were organized in European countries, as well as their main results. The scientific literature on EPR is extensive and most of them describe European experiences; however, no comprehensive systematic review was carried out to assess the cost-effectiveness of EPR for recycling waste, which was the main focus of this review. The review also covered gray literature. Due to the discussion of EU CE strategies that resulted in changes to the EU Packaging Directive and others, many reports on the EU P-EPR have been produced recently.

In addition, reports from world experiences to improve the WP working conditions and contribute to their inclusion in WM and P-EPR schemes were analyzed. This review aimed to complement the primary data collected on different participatory activities carried out by the researcher and her partners of ORIS - Observatory of Inclusive and Solidarity Recycling (Rutkowski et al 2017), in the action-research projects that they have been developing with Brazilian WP since 2012. Abstracts of 216 registrations were analyzed, resulting in 47 articles, reports, and theses read in full to complement the information in both models.

EU P-EPR data was also collected from participant observation at some professional conferences, seminars and lectures organized in 2019 to analyse how the changes for CE would impact the EU P-EPR schemes. To complete the understanding of the recycling model in Europe, study visits were made to Austria, where the P-EPR is considered effective and well implemented, and to Serbia and North Macedonia, where the WP' action is registered (Mrkajić 2018; Sapuric 2018). In these countries, field observation through technical visits to recycling facilities was carried out for a deeper understanding of packaging recycling processes in Europe, from a practical, operational, and commercial perspective. Data of the EU WP' operation and main achievements were also collected by participatory observation in visits to the places where they operates like scrap yards, dumpsites and others and by some semi-structured interviews with some key informants (Flick 2004 ).

Quantitative results related to packaging recycling rates in European countries were obtained on the EUROSTAT website. For the quantitative analysis of the BR P-EPR achievements, the annual productivity and other business data of a group of 277 Brazilian WP cooperatives, partners in the Brazilian P-EPR Agreement, were analysed. The cooperatives' data were accessed from a database formed by the National Association of the Brazilian WP (ANCAT), organized to compose a measure of the WP's participation in the packaging recycling index in Brazil. This is the first time the data has been used for research.

\section{PACKAGING EXTENDED PRODUCER RE- SPONSIBILITY SYSTEMS}

The concept of EPR is based on the polluter-pays environmental principle, which implies that manufacturers must be charged for the life cycle of their products, including the post-consumer stage. It should lead manufacturers to create take-back programs and support the reuse and recyclability of their products (OECD 2001). These policies generally have a target-oriented approach and not a command-and-control regulation. They can be implemented voluntarily by producers as a "product stewardship" scheme or be mandatory, which is currently the case for packaging in many countries (OECD 2016).

EPR schemes aim to increase the recycling rates of targeted products and materials and encourage innovation on Design-for-Environment (DfE) in producers (Michaellis 
1995; Lindhqvist \& Lifset 1998; Tojo, Lindhqvist and Davis 2001; OECD 2001). EPR leads to a change in responsibility for waste - from governments or municipalities and, therefore, from taxpayers to producers and distributors. In practice, this must mean that producers are responsible for the collection of used products and for the necessary subsequent processes like sorting and other treatments, for eventual recycling / reuse (EC-DGEnv 2012). In most cases, this responsibility is purely financial, with producers being obliged to finance, in whole or in part, the collection of recyclable waste previously under the responsibility of the municipalities with subsequent processes being left to the market. Sometimes they also have a responsibility to organize and carry out part or all these processes (ECDGEnv 2014).

Four main categories of EPR instruments are recognized in different approaches and used for different products worldwide, as summarized in Table 1. They address specific aspects of WM and can be implemented simultaneously. The most widely used policy instruments in EPR are the several arrangements of take-back ( $72 \%$ globally), sometimes in combination with advance disposal rates, the next most used instrument (16\%). Deposit / refund instruments $(11 \%)$ are concentrated in the beverage container and lead-acid battery markets, sometimes in combination with take-back requirements. Other EPR policy instruments - combined upstream taxes / subsidies, recycling content standards and taxes on virgin materials - appear to be used infrequently (OECD, 2016).

Although EPR is, in theory, an individual obligation, producers often exercise their responsibility collectively. Most EPR schemes are operated by producers who organize or support one or more Producer Responsibility Organizations (PROs). These collective systems are said to generate economies of scale, simplify operations and reduce administrative burdens for consumers, retailers, and municipalities, reducing costs for participants (Gui et all 2016; Mayers and Butler 2013). PROs can act in competition with each other or hold the national monopoly and can also manage more than one type of waste and operate in more than one country (Mayers 2007). There is insufficient empirical evidence to determine if a PRO monopoly is more efficient than competing ones (OECD, 2016). Moreover, it is more difficult (and sometimes impossible) to obtain data on fees, costs, and revenues when several PROs are in competition, raising concerns about data availability and system reliability (EC-DGE 2014).

These PROs can be non-profit organizations, which is the most common model, government agencies, quasi-governmental non-profit organizations, or for-profit companies, but in all cases, they are overseen by public institutions. Most PROs charge a fee directly from producers, based on a specific fee structure, and the proceeds are used to pay the costs of collecting, sorting and treating waste, and also administrative and managerial costs (Mayers and Butler 2013). PROs are also responsible for other tasks, such as informing citizens and waste generators about selective collection; document and prove the quantities of waste collected and separated for recycling; bidding and hiring or supervise waste operators for collec- tion and recycling (Mayers 2007), which can be WP co-ops (GiZ 2018; Tearfund et al 2019).

The minimum expected requirements for a P-EPR system must define (OECD 2016; GiZ 2018; EC-DGEnv 2014; OECD 2001): a) the range of products and producers involved in the system; b) the parties involved in the EPR system and the role and responsibilities of each one; $c$ ) the measurement methodology, reporting system and target control methods; and, d) ensure equal treatment and non-discrimination between all implicated actors.

Among the expected results of the EPR are a reduction in waste disposal and an increase in recycling and recovery (OECD 2001; Gupt \& Sahay 2015); greater cooperation and involvement of the private sector in WM (Černiauskaite 2013); achieve quantitative recycling and recovery targets (Cahill; Grimes \& Wilson 2011; Da Cruz et al. 2014); boost the recycling industry and promote efficient secondary markets (Forslind, 2009; Hotta et al 2009; OECD 2001; OECD 2006).

EPR is also seen as a practical way to introduce "green supply chain management" to broaden the focus on resource efficiency (Massaruto 2014) and to help eliminate the cost burden for local governments on plastic waste (EASAC 2020). On the other hand, the impact of EPR on DfE and product innovation is less than expected (Atasu 2018; OECD 2016; Wiesmeth \& Häckl 2011). Although a reduction in the material used in packaging has been reported (Hwang 2007; Gupt \& Sahay 2015), innovation efforts have been more often directed towards classification and recycling techniques than towards product design (Lifset, Atasu \&Tojo 2013; Walls 2006). Difficult recycling packaging, or even non-recyclable, is still widely used in many goods, even long after the introduction of EPR (EC-DGEnv 2014).

\subsection{The European Extended Responsibility to the Packaging Producer Scheme}

The EU Directive on packaging and packaging waste, which was approved in 1994 and updated in 2004, 2005, 2015 and 2018, aims to limit the generation and quantities of packaging waste landfilled by promoting recycling, reuse and other forms of waste recovery (PPWD 1994). This directive, coupled with others related to waste (Scharff 2018), requires all EU members to define a packaging waste management policy to achieve mandatory recycling and recovery rates, as shown in Table 2 . As a result, most EU countries have implemented selective collection of packaging in different waste fractions (glass, plastic, metal, and paper) to meet legal recycling and landfill targets.

In response to these policies, EPR was implemented as an important instrument to support the European waste hierarchy (EC-DGEnv 2014), and an efficient waste management (EU 2018b). PROs were created in most EU countries after the first European packaging waste legislation implemented in Germany in 1990. Mayers (2007) registered 114 PROs for packaging waste organized in 29 European countries; P-EPR schemes have been implemented in 25 of the 28 EU members (EC-DGEnv 2014) and the levy on producer fees for packaging has been identified in all but the UK. 
TABLE 1: EPR instruments, approaches and way of implementation used worldwide.

\begin{tabular}{|c|c|c|c|}
\hline EPR Instruments & Usual approach & Way of implementation & Examples \\
\hline Product take-back requirements & $\begin{array}{l}\text { Recycling and collection targets } \\
\text { defined for a product or material }\end{array}$ & Mandatory or voluntary & $\begin{array}{l}\text { Most used scheme in the World, } \\
\text { high transaction costs }\end{array}$ \\
\hline $\begin{array}{l}\text { Regulations and performance } \\
\text { standards }\end{array}$ & $\begin{array}{l}\text { Minimum recycled content on new } \\
\text { products }\end{array}$ & $\begin{array}{l}\text { Mandatory standards or applied } \\
\text { by industries themselves through } \\
\text { voluntary programmes }\end{array}$ & $\begin{array}{l}\text { Some companies' decision: } 100 \% \\
\text { recycled plastic bottles by } 2025\end{array}$ \\
\hline Information-based instruments & $\begin{array}{l}\text { Reporting requirements, labelling } \\
\text { of products to communicate } \\
\text { consumers about waste separation, } \\
\text { and recyclers about raw materials } \\
\text { in products }\end{array}$ & $\begin{array}{l}\text { Mandatory standards or applied } \\
\text { by industries themselves through } \\
\text { voluntary programmes }\end{array}$ & Recyclability symbols in packaging \\
\hline \multirow[t]{4}{*}{$\begin{array}{l}\text { Economic and market-based } \\
\text { instruments }\end{array}$} & Deposit-refund (DRS) & $\begin{array}{l}\text { Previous deposit is fully or partially } \\
\text { refunded when the product is } \\
\text { returned to a specified location }\end{array}$ & Bottles deposit machine in retailers \\
\hline & Advanced Disposal Fees (ADF) & $\begin{array}{l}\text { Fees at purchase based on the } \\
\text { estimated costs of collection and } \\
\text { treatment, that may be collected by } \\
\text { public or private entities and used to } \\
\text { finance post-consumer treatment of } \\
\text { some products }\end{array}$ & $\begin{array}{l}\text { Used in } 17 \% \text { of the schemes in the } \\
\text { World (PROs) }\end{array}$ \\
\hline & Material taxes & $\begin{array}{l}\text { Taxes on virgin materials or difficult } \\
\text { to recycle materials to create incen- } \\
\text { tives to use secondary (recycled) or } \\
\text { less toxic materials }\end{array}$ & $\begin{array}{l}\text { Appropriated for shifting innovation } \\
\text { in design }\end{array}$ \\
\hline & $\begin{array}{l}\text { Upstream combination tax/subsidy } \\
\text { (UCTS) }\end{array}$ & $\begin{array}{l}\text { Tax paid by producers subsequently } \\
\text { used to subsidise waste treatment }\end{array}$ & Associated to DfE, but less used \\
\hline
\end{tabular}

Source: Elaborated by the author from OECD 2001; 2016

TABLE 2: Recycle and reuse targets for packaging regarding the current EU Directives - Packaging and Packaging Waste Directive (PPWD) and Waste Framework Directive (WFD) updated with Circular Economy Package.

\begin{tabular}{|c|c|c|c|c|c|c|c|c|c|c|c|}
\hline \multicolumn{12}{|c|}{ Waste classification } \\
\hline & & \multicolumn{2}{|c|}{ Municipal waste } & \multicolumn{2}{|c|}{ Packaging waste (3) } & \multicolumn{6}{|c|}{ Packaging material } \\
\hline & & $\begin{array}{l}\text { Landfill } \\
\text { (max.) }\end{array}$ & $\begin{array}{l}\text { Recycling/ } \\
\text { reuse } \\
\text { (min.) }\end{array}$ & $\begin{array}{l}\text { Recycling } \\
\text { (min.) }\end{array}$ & $\begin{array}{l}\text { Recovered } \\
\text { or WtE } \\
\text { (min.) }\end{array}$ & $\begin{array}{c}\text { Paper/ } \\
\text { Cardboard }\end{array}$ & Plastic & Glass & $\begin{array}{c}\text { Ferrous } \\
\text { metal }\end{array}$ & Aluminum & Wood \\
\hline \multirow{7}{*}{ 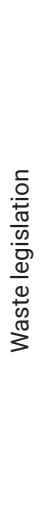 } & $\begin{array}{c}\text { PPWD } \\
2008\end{array}$ & & & $55 \%$ & $60 \%$ & $60 \%$ & $22,5 \%$ & $60 \%$ & $50 \%$ & $50 \%$ & $15 \%$ \\
\hline & $\begin{array}{c}\text { PPWD } \\
2025\end{array}$ & & & $65 \%$ & $(2)$ & $75 \%$ & $50 \%$ & $70 \%$ & $70 \%$ & $50 \%$ & $25 \%$ \\
\hline & $\begin{array}{c}\text { PPWD } \\
2030\end{array}$ & & & $70 \%$ & (2) & $85 \%$ & $55 \%$ & $75 \%$ & $80 \%$ & $60 \%$ & $30 \%$ \\
\hline & $\begin{array}{l}\text { WFD } \\
2020\end{array}$ & (1) & $50 \%$ & & & & & & & & \\
\hline & $\begin{array}{l}\text { WFD } \\
2025\end{array}$ & & $55 \%$ & & & & & & & & \\
\hline & $\begin{array}{l}\text { WFD } \\
2030\end{array}$ & & $60 \%$ & & & & & & & & \\
\hline & $\begin{array}{l}\text { WFD } \\
2035\end{array}$ & $10 \%$ & $65 \%$ & & & & & & & & \\
\hline
\end{tabular}

(1) Landfill ban on separately collected plastic, metal, glass, paper, cardboard and biowaste. Target to be redefined after 2024. (2) Incinerated packaging can't anymore be counted in the recycling/ recovered targets (3) Equal to the amount of packaging placed on the market. Source: Elaborated by the author from Scharff 2018; WFD 1998; PPWD 1994; EU 2018; EU 2018a; EU 2018 b.

These schemes essentially oblige packaging producers to financially support to varying degrees the implementation of packaging waste recycling (EC-DGEnv 2012).

Some common characteristics can be observed in the EU EPR: 1. Normally, one operator organizes the system for several companies; 2 . National fees based on material-ton/packing to finance cost of selective collection-waste sorting are paid by producers and importers; 3 . Collected waste are sold to independent actors who classify and sell it to recyclers or incinerators; 4 . Revenues from sales of secondary material help offset the financial contributions of producers and importers to EPR schemes. Figure 1 schematically represents this model.

Producers generally join national collective compliance schemes, organizing producer responsibility organizations (PROs) to be the operator of EPR requirements. PROs differ mainly in terms of organizational structure, specific operations, costs and reporting requirements, but they all serve the same basic function. The recycling, logistics and waste companies hired by the PROs carry out daily operations to 


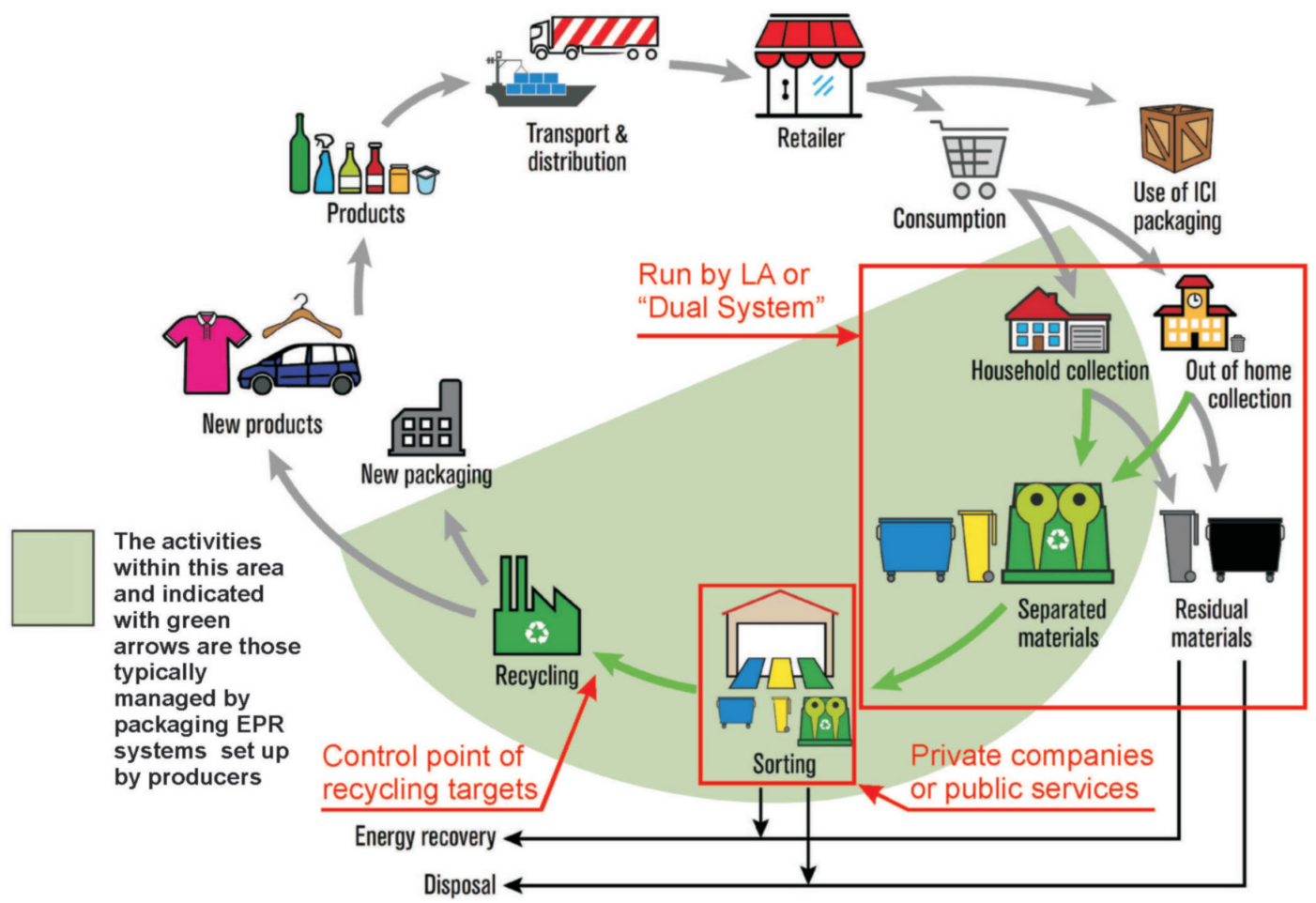

FIGURE 1: EU P-EPR operational model (LA = Local Authorities) Source: adapted from EUROPEN, 2014.

ensure that packaging is collected at designated municipal collection points and treated as needed. PROs recover their costs from producers either through flat rates or by allocating actual costs according to the relative quantity of products each producer sells over a period - usually semi-annually or annually. Most of the time PRO collection services are provided by public WM services, run by local authorities (LA) and sorting services are provided by recycling companies. However, in some cases, there is a "dual system" when PROs and municipalities manage separate collection systems. In others, the LA act also as providers of sorting waste packaging for the PROs, directly or by subcontractors.

The EPR system is considered a factor that boosted the recycling industry in Europe and is also considered important for financing selective collection of waste which, for operational reasons, is generally more expensive than a conventional collection (EC-DGEnv 2014). It is considered also pivotal for achieving the EU packaging waste recycling targets (EU 2018b). The role of PROs has become important in its implementation since they provide an interface for organizing financial transactions, waste collections, and communications between governments, producers, waste treatment companies, retailers, and more than 80,000 municipalities in Europe.

The packaging recycling indices are calculated annually by comparing the total weight of packaging waste entering recycling operations with the quantity of packaging placed on the market in each Member State (MS) and for each packaging raw material. In an attempt to achieve the principles of the $\mathrm{CE}$, increasing recycling targets were recently defined for Municipal and packaging waste as well as for all packaging raw material but aluminum(Table 2).

The EPR scheme operation has common features in EU MS, but small differences can also be observed. For each operation model and different geographic / landscape conditions, the measured / estimated cost for the full cost of collection, classification and treatment of selectively collected packaging waste may be different as well as the fees. This cost may also include costs for handling packaging-containing commingled waste; for public information and awareness to ensure consumer participation in the scheme; for litter prevention and management; and costs related to the enforcement and surveillance of the EPR system, which includes audits and measures against "free-riders" (EC-DGEnv 2012).

In the Austrian EPR system, for instance, fees must cover the costs of collecting packaging in commingled waste, while in the UK, they cover only $10 \%$ of the total cost for packaging waste collection and recycling (EC-DGEnv 2014). In Germany, PRO bears the total cost to collect packaging due to the choice of a "dual" system; in the Netherlands, the full cost is covered in the WM bill, while most countries have adopted a cost-sharing mechanism between producers and WM public services (Massaruto 2014). In Belgium, LA are reimbursed for a defined frequency and density of collection and in France, P-EPR is supposed to cover $80 \%$ of a 'net optimised costs' system, the reference costs are based on the optimal functioning of the collection and sorting operations (EC-DGEnv 2014). Da Cruz et al (2014) and Da Cruz, Simões and Marques (2014) failed to evidence that the industry bears all the costs of managing and recycling packaging waste in any of the EU countries analysed.

In addition, as shown in Figure 2, there seems to be no 


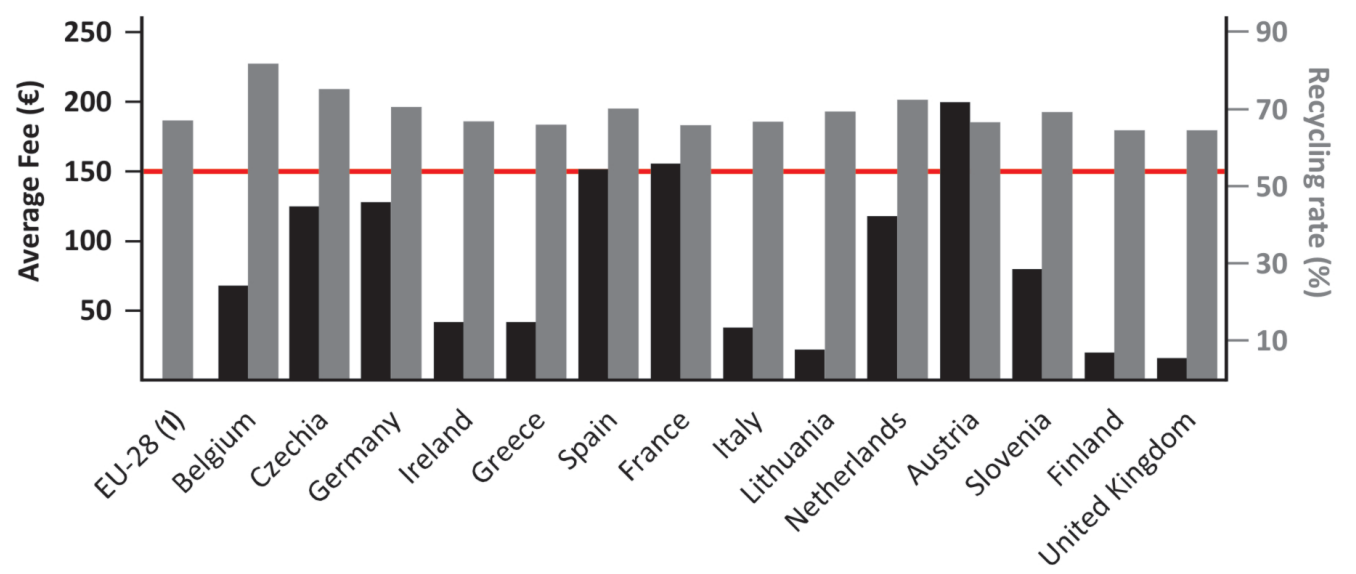

Average Fee Recycling rate $\quad$ Recycling Rate Target $(2016)=55 \%$

FIGURE 2: Recycling rates (\%) of paper, plastic, metal and glass household packaging in some EU countries (right axis) and average fees charged to packaging producers $(€)$ per ton of packaging put on the market(left axis), based on the average share of paper, plastic and glass in total waste packaging (domestic and industrial /commercial) in the EU-28, year of 2016 . EU-28 ( ${ }^{1}$ ) represents the average recycling rate for EU-28 countries. Source: Elaborated by the author from EC-DGEnv 2014; EUROSTAT, 2019.

direct correlation between the fees paid and the recycling rates obtained. It is also difficult to compare the cost-effectiveness due to the lack of transparency regarding the financial aspects and the technical performance of the EPR schemes. The amount of waste generated, collected and treated is hardly comparable between MS, because they are calculated in different ways, with quality issues; costs are not always aggregated on a national scale; data on quantities of packaging placed on the market, financial information and flows are not always available, as well as information on fees paid by producers and the costs they must cover (EC-DGEnv 2014).

There are also different scopes in the P-EPR between EU countries - some cover only household packaging waste, while in other countries commercial and industrial packaging waste can also count towards recycling targets (Cahill, Grimes and Wilson 2011). Commercial and industrial packaging waste is known to be easier to collect and sort (Massaruto 2014; EEA 2005), which reinforces criticisms about the accuracy of comparing recycling rates in EU MS (Hogg et al 2018). Concentrating efforts on commercial and industrial waste also raises concerns, since it is in the domestic flow that most of the packaging recycling challenges lie (Lerpeniere \& Cook 2018). Other environmental criticisms arise because fees are not based on principles of ecological modulation. Although the rates are different for different raw materials, the fee diversification does not consider detailed information on the recycling of subfractions. For example, there is a single fee for all kind of plastics, although eco-modulated P-EPR rates should penalize the use of plastics that are difficult to recycle (Brouillat \& Oltra 2012).

\subsection{Brazilian Packaging Extended Producer Respon- sibility: an inclusive scheme}

Brazil, Argentina, Ecuador, Colombia and several countries in Latin America and the Caribbean (LAC), including the OECD's members Chile and Mexico, recently took steps to implement their first P-EPR systems. In these countries and in other LMIC countries, the recycling of waste depends on the action of the WP, which is the main and most visible part of the so-called Informal Recycling Sector (IRS).

In Brazil, the recognition of waste pickers as workers "recyclable material pickers" was defined by law in 2002 and, since then, some public policies have been developed to integrate the WP into the formal economy. The Brazilian Solid Waste Policy (PNRS in Portuguese), approved in 2010 , defines a hierarchy for the treatment of waste, recognizes waste as a resource of economic and social value and ratifies WP cooperatives (WP co-ops), the main representative of the IRS in Brazil, as an important player of the urban waste recycling process.

As usual in other countries, the selective collection of domestic solid waste in Brazil is part of the public sanitation and urban cleaning services, under the responsibility of LA. LA can hire private service operators to provide these services, which can be a company or a WP co-op, but only WP co-ops can be contracted without public bidding.

The PNRS (2010) prohibits the landfilling of recyclable waste and defines producer compliance for some hazardous waste, including packaging. The packaging life cycle is under "shared responsibility": LA must offer selective recyclable collection as part of municipal WM and citizens must dispose of recyclable materials separately from other waste. Citizens can also be charged with waste fees. Manufacturers, importers, distributors, and traders must encourage and maximize reuse and recycling, improving the design of their products and manufacturing processes. They also need to comply the diversion of packaging to landfills, through an agreement with the states and federal governments. This "reverse logistics" system, as it was called in the legislation, should be implemented in partnership with the WP co-ops.

Although urban waste collection is carried out in almost $100 \%$ of Brazilian municipalities, selective waste collection is poorly implemented despite the PNRS. Less 
than $40 \%$ of municipalities have implemented this service, which reaches all households in less than $10 \%$ of them. This results that only $4.1 \%$ of the 62.8 million tons of waste generated annually in Brazil - 2.6 million tons / year which represents around $14 \%$ of the total recyclable waste- is collected selectively (SNIS 2018). However, industries in Brazil report significant recycling rates for several recyclable waste (Rutkowski \& Rutkowski 2017) which are growing each year (IBGE 2015). The PET recycling rate in Brazil, for example, is reported to be higher than in the USA and many EU countries; according to the industry, $83 \%$ of recycled PET is supplied by WP co-ops (ABIPET 2016; ABIPET 2019). In most Brazilian cities, selective collection of waste is provided or depends on the WP co-ops' initiative, without the support of LA.

The Brazilian waste recycling supply chain can be described as consisting of two parts (Figure 3) (Rutkowski 2008). The most visible component is a "value chain", in which recyclable material becomes the raw material for paper, plastic, etc production chain. This chain depends on a "service chain" needed to transform mixed waste materials into a resource (Scheinberg\&Simpson 2015). WP coops play a valuable role in these two chains and are at the intersection between them (Rutkowski\&Rutkowski 2017). This way of action, known in Brazil as 'Solidarity Selective
Collection' (CSS in Portuguese initials), has been observed also in other LMIC (Ferronato et al 2019; Giovannini \&Huybrechts 2017; Batista et al 2018; Scheinberg et al. 2016; Nahman 2010).

CSS is a "social" technology built from the WP's practical knowledge and skills, organized in a Social and Solidarity Economy framework (Rutkowski \& Rutkowski 2015; Lima et al 201; Gutberlet 2009). Through CSS, WP co-ops divert household packaging from landfills for recycling. Door-to-door CSS expands the selective packaging collection route, increases the volumes collected, reduces operating costs and reduces GHG emissions (King \& Gutberlet 2013). WP co-ops also raise people's awareness to carry on better separation of recyclables through recycling education, which includes letting them know that the material will be turned into income for WP families (Rutkowski \& Rutkowski 2015). In WP co-ops' sheds, packaging is manually classified into more than 20 different subcategories, using visual and tactile sorting skills and adjusted to the quality requirements of secondary material buyers, which implies a substantial and sophisticated contribution to waste recycling (Purshouse et al 2017).

In some large cities, private cleaning companies contracted by LA are responsible for collecting recyclable waste from door to door (SNIS 2018), and WP co-ops are

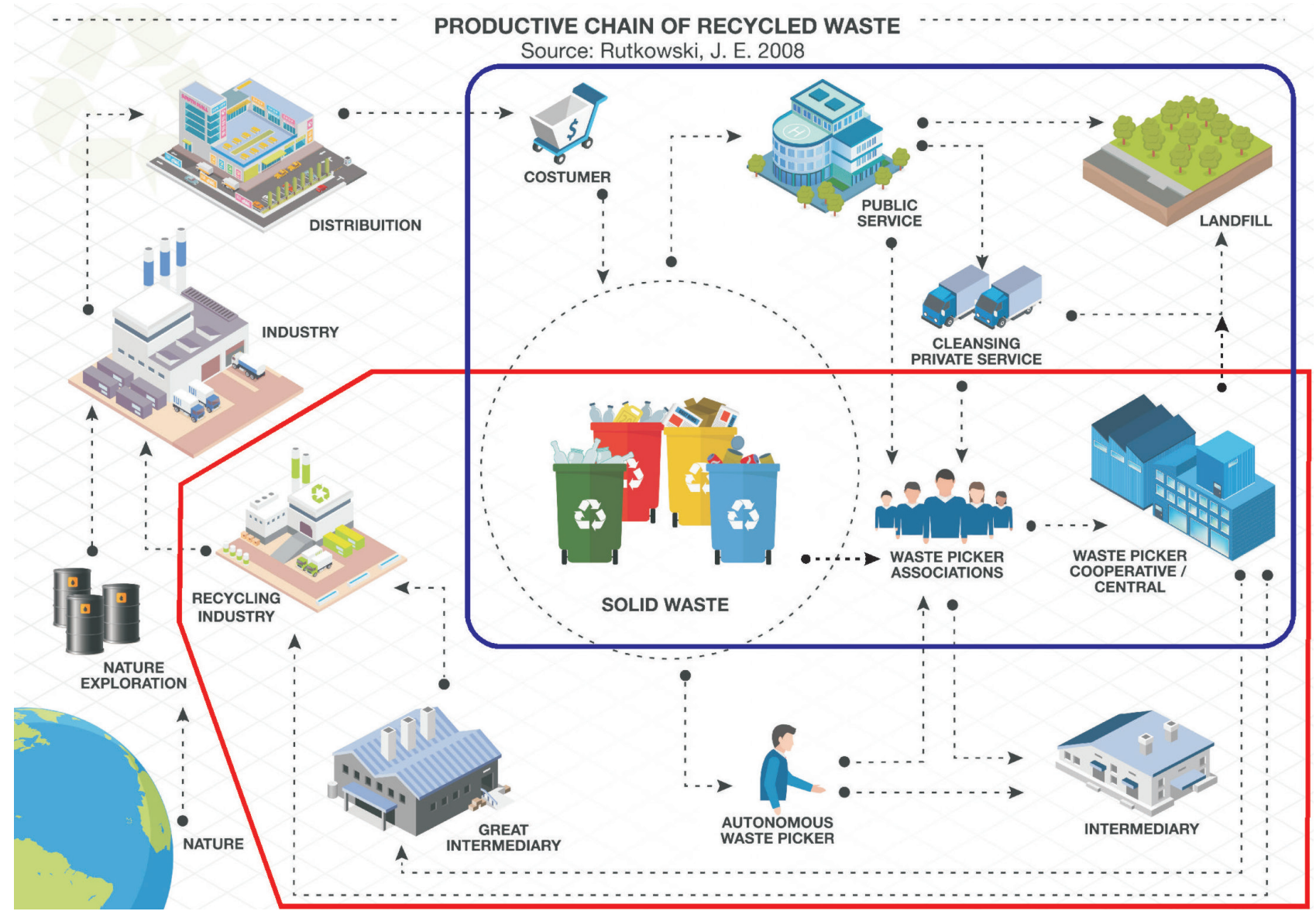

FIGURE 3: Waste recycling supply chain in Brazil. Blue line marks the service waste management chain and the red one marks the value recycling chain. They are interconnected by the WP co-ops that play paramount roles in both. Source: Rutkowski 2008; Rutkowski\&Rutkowski 2017. 
responsible for the sorting, packaging, storage, marketing of the material, acting as non-automated Material Recycling Facilities (MRF) (Purshouse et al. 2017).The packaging can also be recovered, even if they have been discarded by householders without prior separation. In these cases, the autonomous and independent "street WP" picks them in trash bins and, using their carts or big bags, takes them to WP co-ops' sheds or to scrap yards. In many cities, a smartphone app offers a connection service between residents and the street WP for donations of recyclable materials. Scrap yards act as intermediary businesses in the recycling value chain, collecting recyclable materials also from commercial and industrial organizations, sometimes buying these materials, sometimes receiving them as donations in exchange for offering a waste correct disposal (Rutkowski \&Rutkowski 2017).

BR P-EPR schemes were organized considering this context and recycling actors, as shown in Figure 4 (CEMPRE, 2018). LA is not directly involved in the system, although in many cities WP co-ops work in partnership with them. Producers provide financial support to WP co-ops, which report them data related to recyclable materials marketed to compose recycling targets. Packaging producers also implement a "dual" system to receive voluntary delivery of recyclable materials (PEVs in Portuguese initials) and to promote information to improve citizens willingness to recycle. The Brazilian Government's Environmental System is responsible for controlling targets achievement.

The relationship between some large packaging companies and WP co-ops has been experienced at LAC since the first decade of the 2000s (IRR 2018; Fernandes 2016). These companies have offered support to WP co-ops through social-environmental responsibility actions. This model has been replicated in different countries (DANONE ECOSYSTEM 2016). The BR P-EPR scheme, implemented in 2015 by an agreement between a coalition formed by about 4000 companies from 22 different business sectors and the BR government, was based on these experiences and contributed to formalize the model (Demajorovic \& Massote 2017; IRR 2018a). The goal was to reduce packaging waste disposal in landfills by $22 \%$ and increase the recovery of dry waste fraction by $20 \%$ compared to the situation in 2013. The target for landfill diversion must be $45 \%$ by 2031 . The agreement also aims to improve the capacity of WP co-ops, increasing the efficiency and productivity of the recycling sector (CEMPRE 2018).

In BR P-EPR experiences, companies finance non-governmental organizations (NGOs) to offer technical assistance and invest resources in the infrastructure of WP coops, such as building retrofits, maintenance and purchases of machines and trucks. In return, WP co-ops provide information on the monthly amount of recyclables sold. The financial resources offered by producers are negotiated directly between them and the NGOs and are usually not related to the amounts recycled or to the costs of WP services, but they usually cover the costs and revenues of the NGO's operations. NGOs and producers vary in the way they support WP co-ops. ANCAT coordinates the largest experience of the BR P-EPR and organized a national bidding process to choose which WP co-ops would receive financial and technical support each year. In 2019, 277 cooperatives were supported in the P-EPR scheme managed by ANCAT, corresponding to 22,5\% of the 1232 WP co-ops registered on the Brazilian Sanitation Information System (SNIS in Portuguese initials) (SNIS 2018).

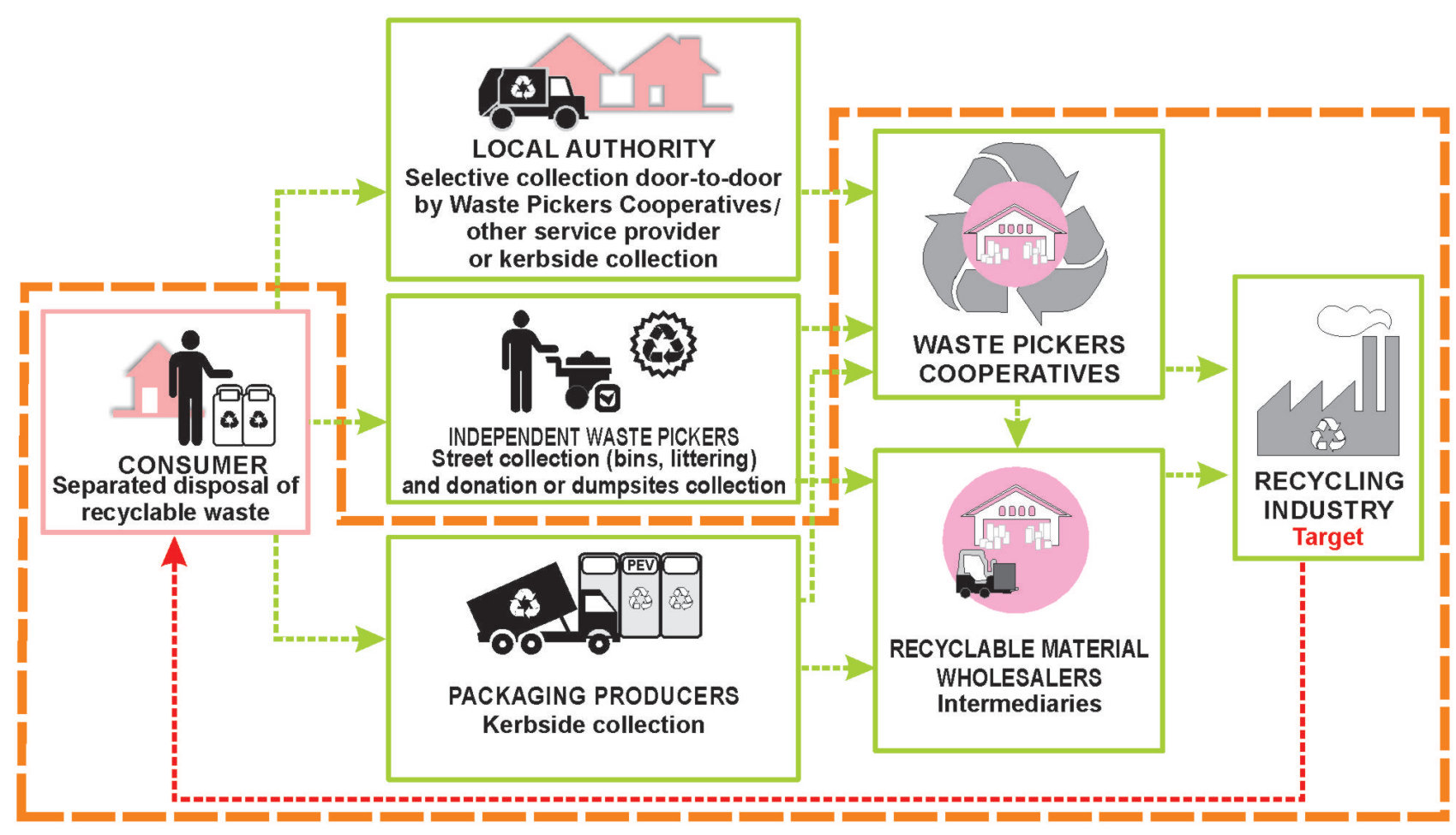

FIGURE 4: Flow diagram and actors involved on Brazilian P-EPR. Orange line marks the action field of P-EPR. Source: CEMPRE 2018. 
The traceability of the BR P-EPR scheme managed by ANCAT is provided by sales invoices from the WP co-ops registered in a database, implemented in 2017. This database also includes information on the WP's income and the material selling prices. This database was the basis for the first Brazilian Recycling Yearbook, launched in 2019, which aims to annually record the WP' contribution to recycling in Brazil. This was a remarkable innovation because it is extremely difficult to quantify the IRS' contribution to recycling (Burcea 2015).

The ANCAT database records that, from 2017 to 2019, WP co-ops diverted 168,101 tons of recyclables from waste, yielding a cumulative cost savings of more than U\$ 4.0 Million to municipalities and providing additional services worth another U\$ 20.3 Million (ANCAT 2020). In 2019 WP co-ops recycled $9.9 \%$ of all packaging market in companies involved in one of the P-EPR programs managed by ANCAT, the "Recycle for Brazil" program (ANCAT 2020). ANCAT data also disclose that WP co-ops had an average productivity of 48.2 tons / month, representing an average physical productivity of 3.48 tons / month for each WP. This productivity is three times greater than that recorded in the literature for an average autonomous picker, who is said to collect and recycle about $40-50 \mathrm{~kg}$ of recyclable waste daily (Chen et al. 2018).

Data coming from other BR P-EPR experiences also reveal impressive results. The database of the initiative "Novo Ciclo" manage by the NGO INSEA registered that $77 \%$ of PET packaging and $17 \%$ of PS packaging marketed in by Danone in Brazil in 2017 were collected and treated by WP co-ops (INSEA 2018), and SNIS registered that WP co-ops collected $30.7 \%$ of the household waste diverted for recycling in Brazil in 2018 (SNIS 2018).

Figure 5 shows the materials treated by the WP co-ops supported by ANCAT and the respective revenue obtained from different recyclable materials. Note, for example, that although plastic represents just $17 \%$ of the amount of recyclable material sold, this material provides $37 \%$ of sales revenue.

ANCAT (2020) records 17 different types of products marketed as metals, 9 different types of paper and cardboard, including aseptic carton packs, 7 types of glass, 22 different types of plastics and 10 types of electro-electronic waste. There are also different selling prices for these materials, depending on the geographic region of collection and trade (Table 3). The South and Southeast regions are those where selective collection is more widely implemented (SNIS 2018) which should improve the quality of the recyclables, but the differences in the sale prices of recyclable materials can also be related to the market context and the recycling industry in each of these regions (Rutkowski \& Rutkowski 2017).

Figure 6 shows the results of the BR P-EPR scheme related to improving the operational capacity of WP coops, in three different phases in the timeline. Phase I indicates the baseline diagnosis of the cooperatives when the P-EPR scheme was started; Phase II is the diagnostic in 2018 and Phase III the situation in 2019. The conditions of management and operation of the WP co-ops, which are self-managed companies organized under the Social and Solidarity Economy (SSE), have been continuously improved in all seven aspects monitored. The financial assistance received contributed to improve working conditions, operational and workforce management and, consequently, their overall productivity. Many cooperatives could be legalized due to better administrative organization, regularized accounting procedures and settlement of eventual debts, which, in turn, facilitated their relationship with the recycling sector, LA and other partners. The financial and administrative stability also contributed to the systematization and strengthening of its internal self-management procedures.

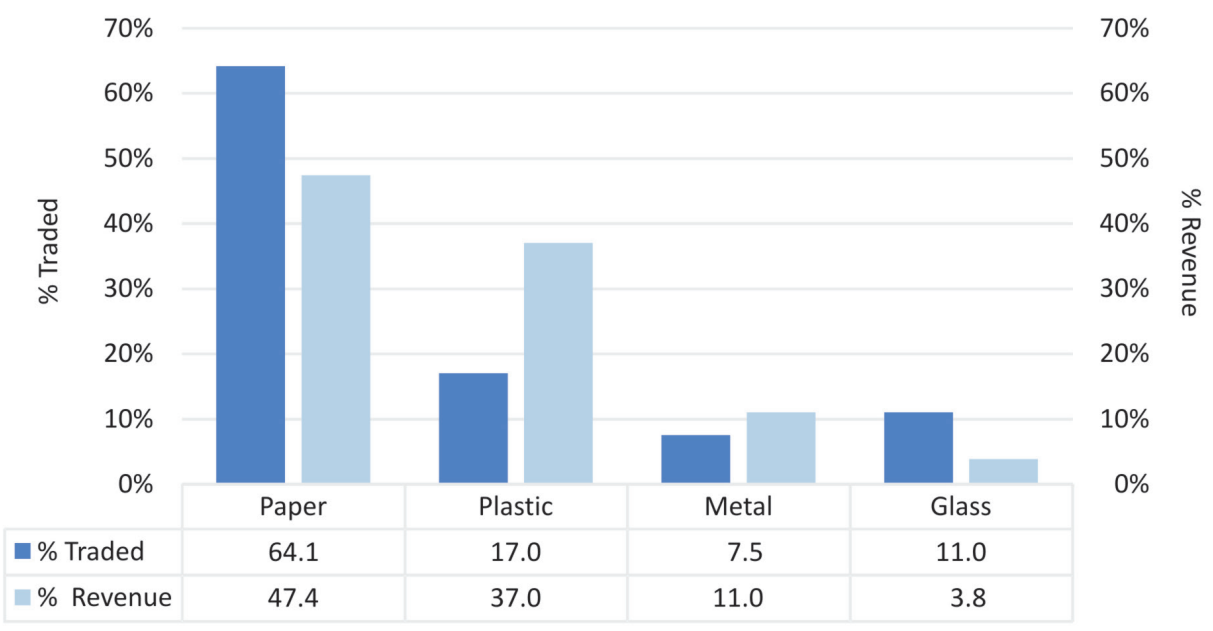

- Percentage of each recyclable material traded among the total traded (2017-2019)

Percentage of total revenue earned from each material (2017-2019)

FIGURE 5: Composition of the packaging waste traded and composition of the revenue obtained by the WP co-ops, between 2017 and 2019 , in percentages of each recyclable material traded among the total quantities traded and percentages of aggregate revenue for each material to the total revenue obtained by WP co-ops. Source: Elaborated by the author from ANCAT (2020). 
TABLE 3: Average selling price of recyclable materials in each Brazilian region in 2019. Bold values highlight the highest and smallest selling price got for each material.

\begin{tabular}{|c|c|c|c|c|}
\hline Region & Metal (US\$/ton) & Paper (US\$/ton) & Plastic (US\$/ton) & Glass (US\$/ton) \\
\hline South & 172,37 & 103,93 & 253,49 & 20,28 \\
\hline Southeast & 205,32 & 116,60 & 266,16 & 25,35 \\
\hline North & 154,63 & 65,91 & 218,00 & 38,02 \\
\hline Center-West & 154,63 & 81,12 & 197,72 & 5,07 \\
\hline Northeast & 215,46 & 86,19 & 263,62 & 22,81 \\
\hline Brazil (average) & 182,51 & 98,86 & 240,81 & 20,28 \\
\hline
\end{tabular}

Source: Elaborated by the author from ANCAT 2020

The support for administrative improvement in WP coops was considered essential to increase WP's income and the ability to be contracted as public service providers. WP generally have an extremely low school experience - $17 \%$ of the WP in the supported cooperatives are illiterate and $60 \%$ have less than 4 years of schooling (ANCAT 2019). Low schooling prohibits most WPs from knowing and using management techniques and tools (Rutkowski 2008), considered essential to ensure traceability of P-EPR schemes and control of the waste services offered (Gutberlet 2015; Demajorovic \& Massote 2017). This knowledge is necessary to facilitate dialogue and networking with waste management and recycling companies (Rutkowski 2013) and, therefore, the inclusion of WP in formal WM and EPR systems.

Financial support from producers partially addresses the lack of access to working capital, a major problem faced by cooperatives in many LMICs (Gutberlet 2009; Rutkowski 2013). WPs organized in cooperatives share activities and responsibilities, which leads to better busi- ness management and better working conditions, allowing them not to have to work in unsanitary conditions, in dumps or on the streets as before (Demajorovic et al. 2014; Gutberlet 2015). They can sell recyclable materials in better conditions than they could as individuals (Medina, 2000; Gonçalves-Dias and Teodósio 2006; Rutkowski\&Rutkowski 2017); they reduce the transaction costs of their activities (Rutkowski 2013), doing so under a technology that proves to be energy efficient and socially and environmentally sound (Gunsilius et al. 2011; King \& Gutberlet 2013). They are also empowered by being involved in waste management and recycling chains preserving their livelihood (Gutberlet 2008; Gunsilius et al. 2011; Rutkowski \& Rutkowski 2015; Dias, 2016). This support, therefore, helps to increase not only the WP co-ops sustainability but could increase the productivity and overall efficiency of the waste recycling system, improving the ability of producers to meet the packaging recycling targets and their commitments for recycling plastics worldwide.

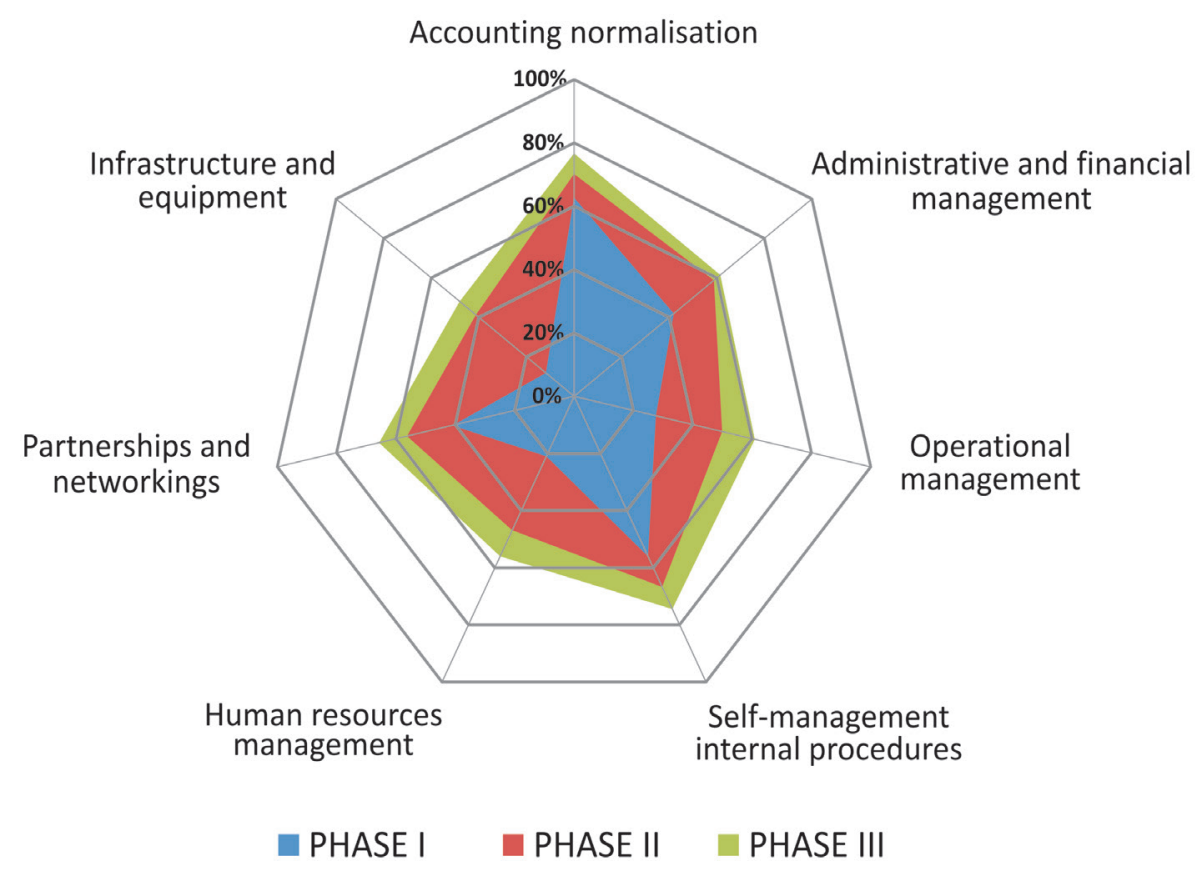

FIGURE 6: Evaluation of the management and operational capacity of the WP co-ops, in three distinct phases. Phase I indicates the cooperatives' baseline diagnosis when the P-EPR scheme was started; Phase II is the situation diagnosed in 2018 and Phase III is the situation in 2019.Source: ANCAT 2020. 
4. LEARNING FROM TWO MODELS FOR AN EQUITABLE AND INCLUSIVE EXTENDED PRODUCERS RESPONSIBILITY FOR PACKAGING SCHEME

\subsection{Comparing the EU and Brazil P-EPR models}

Table 4 summarizes the main characteristics of the two models - the organizational similarities and the different approaches, such as the roles of the stakeholders. It is noteworthy that although organized in a country of continental dimensions, the BR P-EPR scheme operates without a PRO having been organized and without involvement of the LA. The traceability of the data raises criticism in both systems. Also, in both, EPR schemes help to reduce WM costs but do not bear the full cost. It was not possible to say which one is less costly to companies and which is

TABLE 4: Summarized main characteristics of the two studied P- EPR models.

\begin{tabular}{|c|c|}
\hline Aspect & EU P-EPR \\
\hline Principles & $\begin{array}{l}\text { Polluter pays principle and Circular Economy are clearly } \\
\text { expressed in legislation }\end{array}$ \\
\hline Legal Framework & $\begin{array}{l}\text { Directive 94/62/EC and amendments } \\
\text { Directive 2008/98/EC and amendments }\end{array}$ \\
\hline Targets & $\begin{array}{l}\text { Related to } \% \text { of recycled packaging waste: } 50 \% \text { of munici- } \\
\text { pal waste and } 55 \% \text { of packaging waste should be recycled } \\
\text { / reused; }\end{array}$ \\
\hline Role of producers & $\begin{array}{l}\text { Producers must organize and / or finance the collection, } \\
\text { transport, and pre-treatment processes necessary for } \\
\text { recycling packaging waste. For this, they pay fees defined } \\
\text { for each material and calculated according to the quantity } \\
\text { of packaging sold by each producer. } \\
\text { They must also provide information for recycling on their } \\
\text { packaging. }\end{array}$ \\
\hline Role of LA & $\begin{array}{l}\text { LA are legally responsible for waste management and } \\
\text { for organizing municipal selective collection. In most } \\
\text { countries, they receive financial support from producers to } \\
\text { send packaging for recycling. }\end{array}$ \\
\hline $\begin{array}{l}\text { Packaging waste collec- } \\
\text { tion operators }\end{array}$ & $\begin{array}{l}\text { The collection service is done by public or private waste } \\
\text { collection service providers hired by LA }\end{array}$ \\
\hline $\begin{array}{l}\text { Pre-treatment processes } \\
\text { for packaging recycling }\end{array}$ & $\begin{array}{l}\text { Pre-treatment processes for packaging recycling operated } \\
\text { by private companies. Sometimes these processes are } \\
\text { operated at facilities owned by LA. }\end{array}$ \\
\hline Role of PROs & $\begin{array}{l}\text { PROs, organized in different EU's member states, are } \\
\text { financed by fees paid by all or a large part of companies } \\
\text { in an industry but have financial and administrative } \\
\text { independence from them. PROS contract collection and } \\
\text { pre-treatment services for packaging waste from LA and } \\
\text { private companies and are also responsible for recording } \\
\text { and controlling recycling data. }\end{array}$ \\
\hline $\begin{array}{l}\text { Reporting and moni- } \\
\text { toring }\end{array}$ & $\begin{array}{l}\text { Each country has a third part responsible by monitoring } \\
\text { recycling data reported by PROs to Government Environ- } \\
\text { ment Department. }\end{array}$ \\
\hline $\begin{array}{l}\text { Data traceability of the } \\
\text { recycling targets }\end{array}$ & $\begin{array}{l}\text { Not available to the public for alleged commercial } \\
\text { reasons. The accuracy of the applied measurement meth- } \\
\text { odologies is questioned, pointed out as not comparable } \\
\text { between countries. }\end{array}$ \\
\hline $\begin{array}{l}\text { System financial flow } \\
\text { and surveillance }\end{array}$ & $\begin{array}{l}\text { PROs transfer part of the resources paid by producers to } \\
\text { service providers, reducing expenses with waste manage- } \\
\text { ment in the municipalities, but without covering } 100 \% \text { of } \\
\text { the packaging collection costs. The scheme is also con- } \\
\text { sidered to encourage investments in the recycling chain. } \\
\text { The fees paid by companies are defined by the PROs and } \\
\text { therefore competition between the PROs is encouraged. } \\
\text { The financial surveillance of the system is carried out by } \\
\text { the stakeholders of the PROs. Cost- effectiveness not } \\
\text { measured. }\end{array}$ \\
\hline Free riders' control & $\begin{array}{l}\text { Most of the countries have specific legislation and ways } \\
\text { of acting, none of them reported as } 100 \% \text { effective }\end{array}$ \\
\hline
\end{tabular}

BR P-EPR

Polluter pays principle is expressed in law but although waste hierarchy is cited, there is no mention to $C E$.

PNRS- Law 12.305/2010, Decree 7.404/2010, Decree 7.217/ 2010, Sanitation Law n $11.455 / 2007$

Related to\% of packaging waste disposed of in landfills and\% of the fraction of dry waste recovery: reduce packaging waste disposal in landfills by $22 \%$ recovery: reduce packaging waste disposal in landfills by $22 \%$ and increase the recovery of dry waste fraction by $20 \%$ compared to the situation in 2013.

Producers provide financial support for technical assistance and for improving the infrastructure of WP co-ops to increase their productivity in the processes of collection, transportation and pre-treatment for recycling. They are also responsible for implementing points for voluntary packaging delivery (PEVs), in addition to providing consumers with information for packaging recycling.

LA are legally responsible for waste management, however, in most cities, there is no municipal selective collection. LA is not directly involved in the scheme, although in some cities WP coops have service provider contracts with LA or have agreements with them, receiving support such as a warehouse concession, for example.

In most cities, WP co-ops and autonomous WP do the collection. In the biggest cities, the selective collection is done by private service providers hired by LA.

In most cities, this service is operated by WP co-ops and there is an agreement between them and LA.

No PRO organized. Companies act individually, contracting NGOs for intermediating relations with WP co-ops and LA. Most of companies act collectively by mean of their industrial sector association or forming coalitions.

Annual reports on goals and results are presented by companies or their coalitions to Government Environment Departments and published on websites.

Not available to the public for alleged commercial reasons, records based on the sales invoice for waste packaging treated as raw material, easily controllable, but probably registered below the real due to an informal market and the lack of registration and control capacity in WP co-ops.

Expenses with waste management in the municipalities are indirectly reduced by the action of WP co-ops, which reduces the costs of collecting municipal waste and disposal. The scheme also encourages investments in the recycling chain since WP co-ops are an essential link to feed the chain. Companies define how much is transferred to NGOs that define values to be transferred to WP co-ops, but these values are not related to actual costs. No financial surveillance of the system is reported. Cost-effectiveness not measured.

Legislation oblige all producers to participate on the scheme whereas no enforcement mechanism is defined. Some state governments have proposed specific controls recently.

Source: Elaborated by the author 
more cost-effective for recycling targets.

Municipal waste recycling targets differ considerably between the two schemes. First, the BR P-EPR is more recent than the EU P-EPR, as usual, the BR P-EPR starts with modest goals that should grow over time. Second, few municipalities practice selective waste collection and there are no information, education, and awareness programs for the separation of recyclable materials at the source in operation, either by the LA or by EPR schemes. Consequently, a small percentage of municipal waste is diverted from the landfill for recycling by formal WM systems. Even so, the industry registers considerable levels of recycling of papers, metals, and some types of plastics, whose responsibility it attributes to the action of the WP (Rutkowski\&Rutkowski 2017; CEMPRE 2018).

In addition, the share of recyclable waste in the composition of urban waste is greater in the EU MS than in LMIC, as shown in Figure 7. However, although in LMIC, organic matter is the largest fraction of waste, the composition of recyclables collected and treated by WP co-ops (P WP) approximates the composition of EU MS packaging waste (PW EU), as shown in Figure 8. For comparison purposes, this Figure also shows the average percentage of recyclables that make up municipal waste in Brazil (W BR). Thus, concerning the $C E$ perspective, the inclusive P-EPR scheme seems capable to add beneficial innovations to the P-EPR.

As shown in Table 3, the average price of plastics is 2.5 times that of paper but $64 \%$ of the materials marketed by the WP co-ops is paper, which makes up $13.1 \%$ of MSW; while $17 \%$ of the materials marketed by the WP co-ops are plastics, which makes up $13.5 \%$ of MSW, but provides $37 \%$ of WP co-ops' revenue (Figure 5). Despite of WP co-ops efforts to recycle plastics, they have been more effective in recycling paper. In fact, they are limited by householder separation, which is much more efficient for paper than for plastics due to a lack of environmental education. Notwithstanding, WP co-ops value a greater number of subcategories of materials, including plastics, responding to the specific needs of buyers in the recycling industry (Purshouse et al. 2017). They also know better than LAs how to work with the value chains and market the materials (GiZ 2018a).

Typical MRFs in the EU MS usually classify a variety of nine commingled collected materials: corrugated cardboard, newsprint, magazines, and mixed paper make up the paper fraction; the metal fraction is made up of aluminum and ferrous metal. The plastic fraction is composed mainly of HDPE (high-density polyethylene), bottles and pots of PP (polypropylene) and PET (WRAP 2015). For glass, in most EU countries, the main method of collection and classification is the single flow "bring bank" system (WRAP 2006). On the other hand, as described in Section 3.2, the output of the WP co-ops consists of 55 different recyclables subfractions (ANCAT 2020).

There are significant differences between the PW EU and P WP plastic waste subfractions, as shown in Figure 9. Inclusive P-EPR schemes recover different types of plastics but EU P-EPR prioritizes the valuable ones. In the EU MRFs, 3 types of most valuable plastics (PET, HDPE, and PP) compose $80 \%$ of the plastic treated and $1 / 4$ of the ma- terial is unidentified, which means that will be transformed in refused material to recycling. However, WP co-ops sort 11 different plastic subfractions to be recycled. PET, HDPE, and PP represents $56 \%$ of the plastic fraction treated by them.

The outputs of the EU MRF are defined by technological restrictions imposed by the automated process they employ, which, in turn, will influence the selective collection implemented by the LA. The capacity of contracted MRFs will also define the information provided to consumers on what should be separated in each region. The profit rates of the recycling businesses are an important factor for the organization of the system, as they directly impact the costs to be paid by packaging producers. In turn, WP normally collects all available recyclable materials, be it plastic, pa-

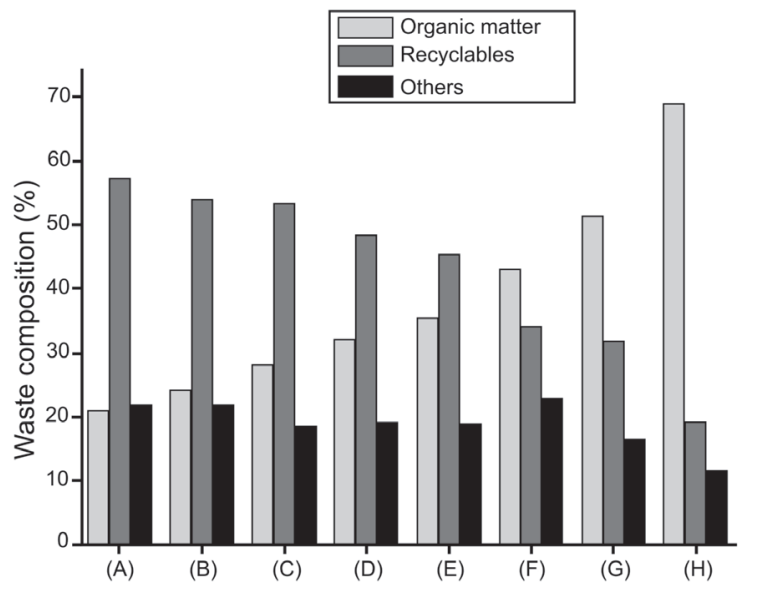

(A) Denmark, 2009; (B) Varna, Bulgaria, 2010; (C) USA, 2015; (D) Germany, 2006; (E) Portugal, urban regions, 2006; (F) Istanbul, Turkey, 2016; (G) Brazil, 2012; (H) Ho Chi Minh, Vietnam, 2016.

FIGURE 7: Waste composition in different countries. Source: Alfaia et al. 2017.

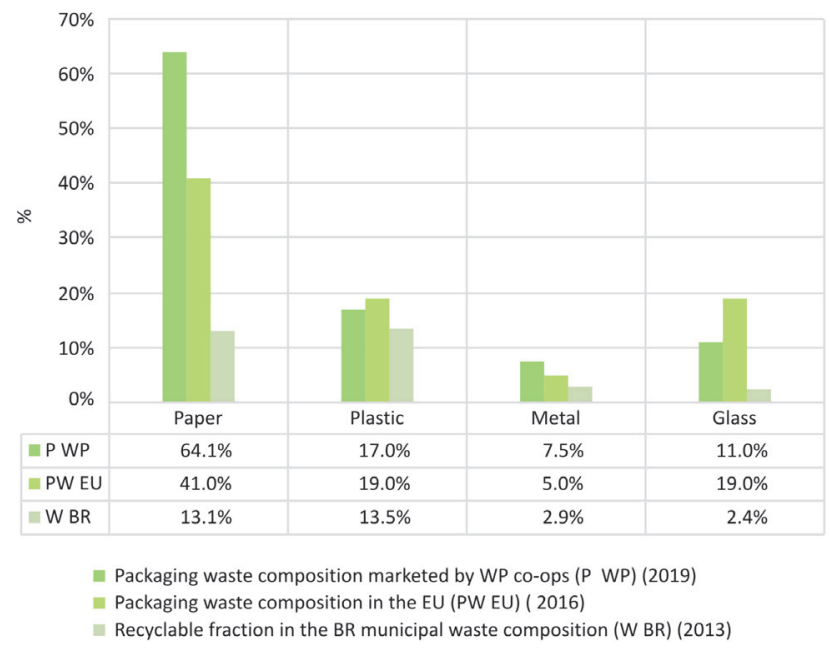

FIGURE 8: Comparison of packaging waste composition in the EU (PW EU), packaging waste marketed by WP co-ops (P WP), and the average percentage of recyclable materials that make up Brazilian municipal waste (W BR) for the main recyclable materials. Source: Elaborated by the author from ANCAT 2020, Eurostat 2019, CEMPRE 2018. 

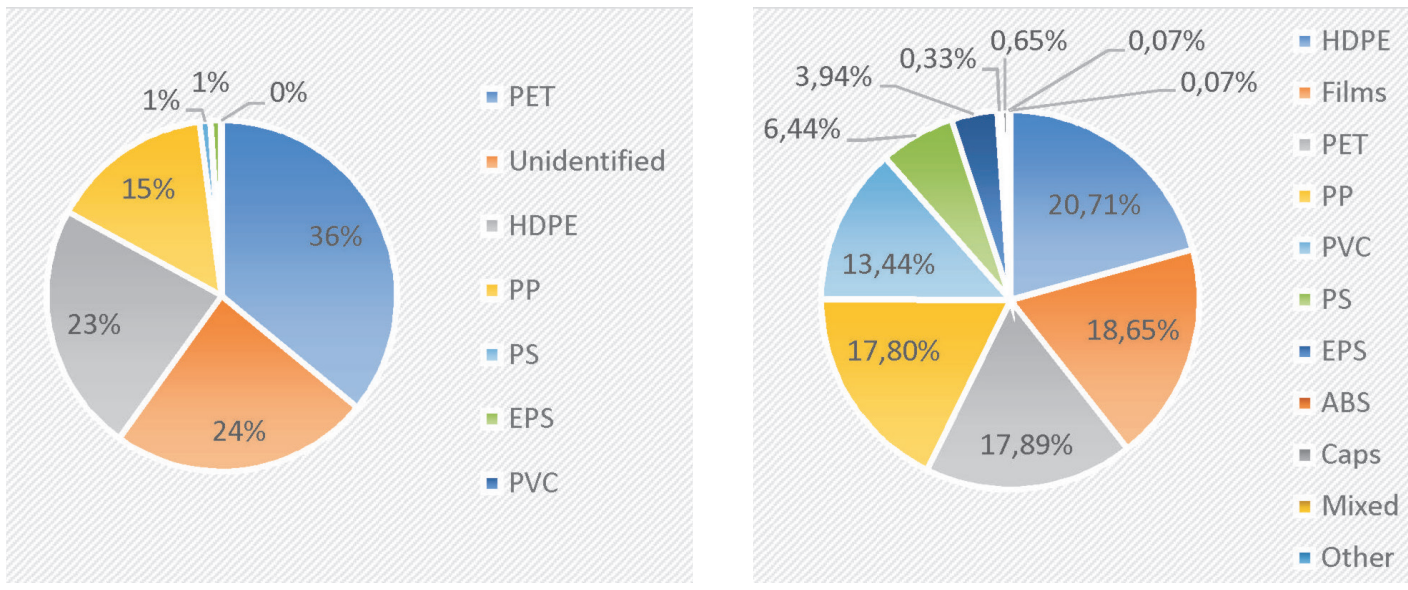

FIGURE 9: Plastic packaging sorting composition in EU MRFs (left) and WP MRFs (right). Source: Elaborated by the author from WRAP 2006; ANCAT 2020.

per, metals, electronics, furniture, clothing and even used frying oil. They are interested in collecting and preparing for sale as much material as possible, since their income comes from what they sell, usually at tiny prices. WP describe themselves as "environmental agents" committed to increasing waste recycling rates. Organized under SSE framework, WP enterprises are based on values such as cooperation, solidarity, trust, self-management, and the feeling of belonging to a common social condition (Rutkowski, 2008; Gutberlet 2015). WP do not just evaluate their businesses in terms of cost-benefit analysis.

In developed countries economic market concerns have been the main drivers of waste recycling rules (Rogoff and Ross, 2016). However, market-driven actions are usually not the most efficient in environmental and social terms; recycling can remain stagnant if supported only by market forces. To meet the objectives of the $\mathrm{CE}$, as much of any recyclable material as possible must be separated from the waste and sent for recycling. In the inclusive model, a wide range of packaging is being effectively recycled due to the modus operandi of the WP.

The BR P-EPR system is operating independently from LA and without a centralized operator. In Europe, the system depends on the organization of PROs, often criticized for lack of transparency in their actions and for environmental results below expectations, such as those related to green innovation, DfE and waste flow treated (EASAC 2020; Lerpeniere \& Cook 2018; EC-DGEnv 2014; Massaruto 2014; da Cruz, Simões \& Marques 2014; Mayers\&Butler 2013; Brouillat \& Oltra 2012). On the other hand, in most developing countries, LA have not been able to implement WM efficiently. Therefore, the inclusive scheme is providing a simpler operation to P-EPR that can be considered an easier system for deployment and dissemination in similar situations.

Nevertheless, in the long run, the system cannot ignore the LA that are legally responsible for WM. As proposed in some EU MS, producers must reimburse LA for the cost of packaging collection. In turn, LA must not ignore that subcontracting the WP co-ops as providers of selective collection services benefits WM, reducing costs, amplify- ing the efficiency of municipal selective collection, and improving the quality of collected material. On the other hand, WP co-ops have also added benefits to the recycling value chain, amplifying resource recovery when performing MRF services. Therefore, the choice of producers to include WP co-ops as agents in P-EPR schemes should also be encouraged.

Finally, EPR is an environmental policy approach that should also develop Design for Environment (DfE) activities and innovation for reduce packaging waste generation. Neither of the two P-EPR models showed evidence of achieving these objectives. In the Brazilian scheme, DfE was not ever mentioned. On the other side, across EU, between 2013 and 2015, the amount of packaging waste generated grew by $6 \%$ suggesting that more effort on waste prevention is needed (EASAC, 2020). An eco-modulation fee to be paid by producers has been suggested as a lever to encourage eco-packaging design at EU-EPR. Regulations in this direction are in place in Germany and under regulation in Italy and France (Scharff 2018). Further studies on these experiences should indicate their validity to reduce waste generation and improve the use of resources in packaging.

\subsection{Proposing an equitable and inclusive P-EPR model}

Performance of EPR schemes are influenced by many factors as population density and country geography; historical development of the waste management infrastructure and existence of complementary waste policy instruments (pay-as-you-throw schemes and landfill taxes, for instance); the value of secondary materials on the national market; awareness and willingness of citizens to participate on the waste recycling effort (EC-DGEnv 2014). When the P-EPR was established in Europe, most municipalities already run well-organized waste management systems and the recycling market was incipient. In this context, the producer's financial resources were used to encouraged private sector's investment in the recycling industry and to modernize waste collection systems through the addition of technology, which resulted in increased operating costs 
(OECD 2016). However, recent studies showed that the decision to implement EPR schemes in some EU countries without considering the IRS prevented the system from achieving its objectives (OECD 2016; Scheinberg et al. 2016; Mrkajić et al. 2018; Wiesmeth et al. 2018; Ferronato et al. 2019).

On the other hand, in LMIC, LA cannot afford expensive waste management systems (UN HABITAT 2010; Giz 2018a; Ferronato et al 2019). As waste management for recycling is poorly implemented by $L A$, the waste recycling system has been developed based on WP's social technology (Scheinberg 2012; Rutkowski \& Rutkowski 2015). In addition, LMIC has an abundant workforce, which in the most can not be employed in modern technological industries and services. The inclusive recycling schemes then appear as an "appropriate technology" (Schumacher 1973), a technologically accessible, labour-intensive, autonomous, decentralized option for upgrading WM in these countries.

Another interesting innovation observed in the BR P-EPR scheme related to CE is providing mutual learning and support for both stakeholders in relation to recycling issues. Producers can better understand the challenges of recyclability because WP are able to clearly indicate which materials cannot be recycled due to restrictions from the market. This information has helped producers to take measures to improve the recyclability of their packaging (Demajorovic \& Massote 2017; DANONE ECOSYSTEM, 2016). Waste pickers, in turn, improved their learning about the recycling industry, due to the opportunities created by packaging producers to overlap with intermediaries in the recycling value chain. Nationally organized into cooperative networks, Brazilian WP are transforming their position in the recycling sector. This type of learning and networking between different economic groups is an interesting innovation and support for new approaches required for the Circular and Green economies around the world.

Thus, the modernization of the WM in the LMIC must be made from the improvements in the conditions of the WP in operating the CSS. Figure 10 summarizes the benefits that the inclusion of WP co-ops could bring to cities towards an integrated and sustainable WM. Due to the improvement of the municipal WM and the livelihoods of a vulnerable urban population, the scheme results in an affordable and efficient alternative for the implementation of ISWM in emerging countries.

Figure 11 represents schematically a proposal for an equitable and inclusive P-EPR. The formalization of WP coops as a provider of municipal selective waste collection services for LA and as a provider of sorting and pre-treatment services for recyclables for packaging producers is the answer to the research question on how waste pickers should be invited to work with the formal WM system to achieve an ISWM and make cities more sustainable and inclusive. Based on the polluter pays principle, packaging producers should be responsible for financing this system in LMIC by paying fees that, together with the householders' WM fees, should cover the total costs of both services. Further research is needed to suggest how these costs can be fairly defined and to assess what is the best governance needed to collect and manage these fees. As well as to improve data collection and assessment on EPR and waste management. Such aspects are highly criticized in both EU and BR schemes.

Learning how to work in an inclusive operational mode

Inclusive P-EPR contribution to Integrated Sustainable Waste Management

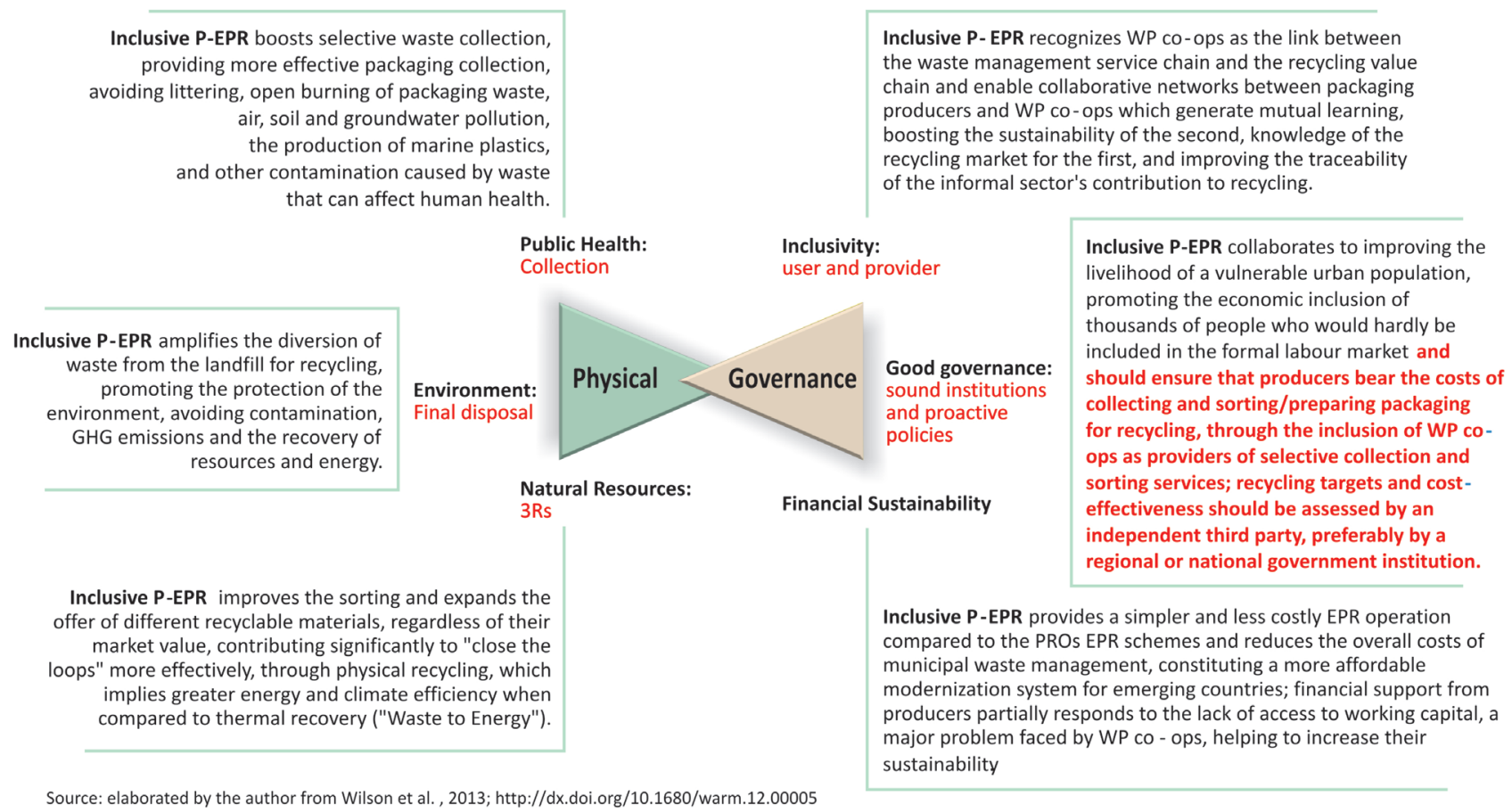

FIGURE 10: Inclusive EPR schemes contribution to the Integrated Sustainable Municipal Waste Management. Source: Elaborated by the author from Wilson et al. 2013. 


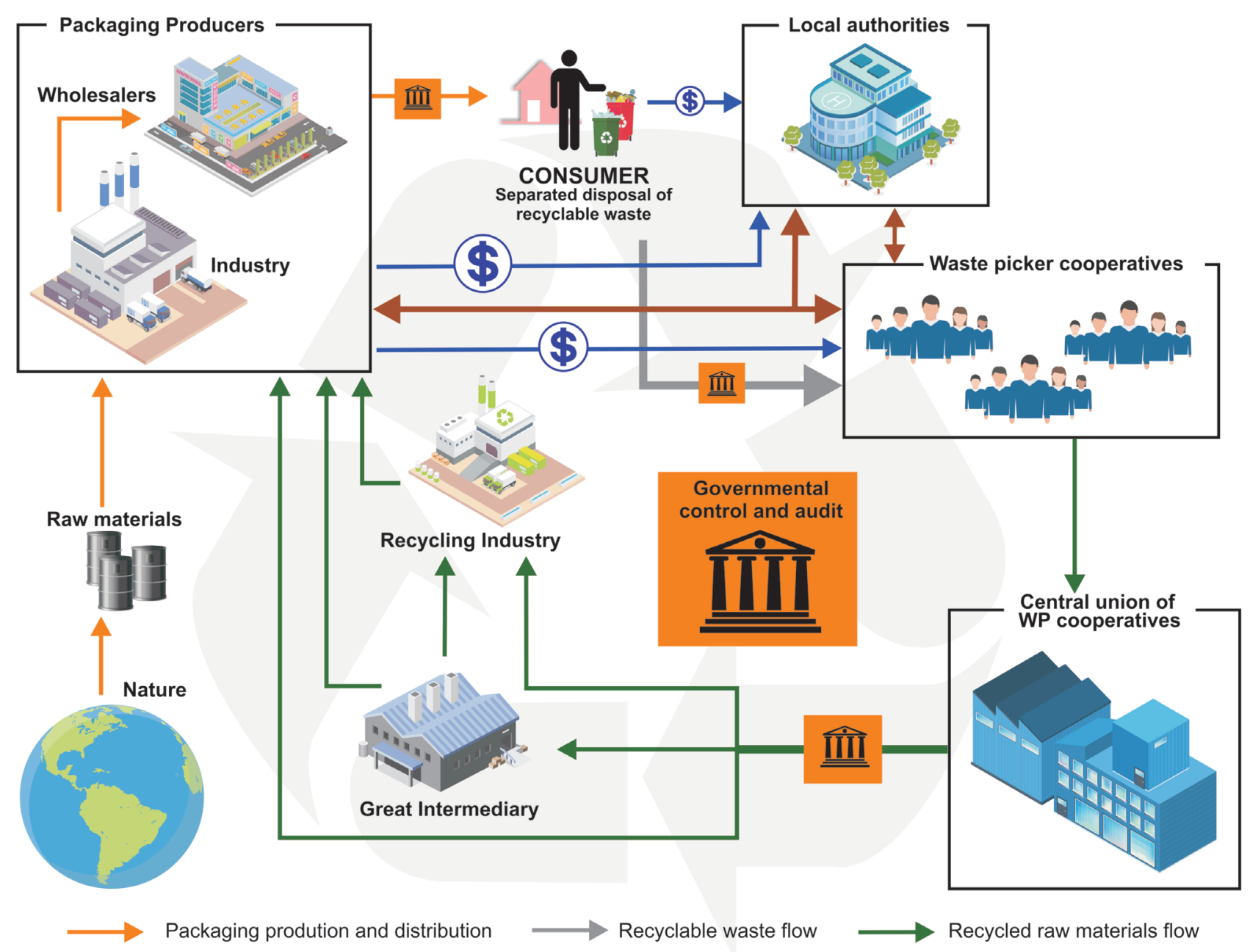

(\$) Money flow

Commercial agreements

Control and audit points of recycling targets

FIGURE 11: Schematical representation of an Equitable and Inclusive P-EPR scheme. Source: Elaborated by the author.

can be crucial to achieve increasing plastic recycling targets agreed by packaging producers worldwide and important to achieve the ambitious EU waste recovery and diversion targets listed in Table 2. Particularly in those EU countries where IRS activities have been imputed to meet, exceed, or at least be indispensable to achieve EU objectives for recycling and recovery, such as for some Eastern EU countries with a largely Roma IRS (Scheinberg et al. 2016; Mrkajić et al. 2018; Ferronato et al. 2019; da Cruz et al. 2014 ; GiZ 2018a). It would also be beneficial for improving the local recycling industry due to the increased availability of diverse secondary raw materials, and for creating green jobs capable of absorbing unskilled labour.

\section{CONCLUSIONS}

After a comparative analysis between the Brazilian and EU EPR schemes for packaging, the research highlighted some aspects and advantageous results of the contribution of the inclusive EPR scheme to increase the efficiency of the municipal WM in resource recovery. An equitable and inclusive P-EPR is proposed as a simpler and less expen- sive innovative solution for the implementation of packaging EPR, constituting a more accessible WM modernization system for emerging countries, including some in the EU.

The study also showed that improvements in the EPR schemes must be implemented. The lack of strong and structured initiatives to improve the separation of dry waste at the source and the involvement of LA as an interested party prevented the BR P-EPR scheme from rapidly increasing recycling rates. These actions can not only improve overall waste recycling rates, but also improve WPs' livelihoods, since a large part of their income depends on the sale of materials.

It is also observed that just defining and controlling waste recycling goals does not necessarily result in real improvements in the general waste management system. Both the EU and BR P-EPR systems do not have effective cost and cost-effectiviness control, which could guarantee efficiency improvements in WM policies.

Reporting and data control on EPR and WM also need to be improved and harmonized to ensure efficient implementation of the expected environmental objectives of EPR schemes. This is not an exclusive defect of the inclusive 
P-EPR system, but it seems to be related to the inability of governments to make companies agree to pay real recycling costs, as well as to reduce the quantities of marketed packaging, which can be observed throughout the world.

However, neither these nor other aspects described seem to prevent the inclusive P-EPR model from being transposed to other countries where the presence of waste pickers is registered, despite the political and institutional issues that may arise and need to be addressed.

The inclusive and equitable P-EPR scheme is presented as a solution for the inclusion of the IRS in the WM, as well as to achieve the ISWM in LMIC. The scheme can make cities more sustainable, inclusive, and capable of improving global recycling rates and reaching the highest plastic recycling targets agreed by many packaging producers towards the Circular Economy.

\section{FUNDING}

The research has been sponsored by the European Union's Horizon 2020 Research and Innovation Programme under the Marie Skłodowska-Curie grant agreement No [792855].

\section{AKNOWLEDGEMENTS}

The author would like to thank the National Association of Waste Pickers - ANCAT, which allowed access to the documents and database of the Sectorial Packaging Agreement in Brazil and to all colleagues at ORIS - Observatory for Inclusive and Solidarity Recycling, whose ideas, diverse research and knowledge have been pivotal for the understanding of the IRS in Brazil.

Special thanks to Dr. Gary Dymski, from Leeds University Business School, for offering economic ideas and concepts and for the partnership that enabled the research to be being developed at the University of Leeds.

\section{REFERENCES}

ABIPET (2016) Census of PET Recycling in Brazil. http://www.abipet.org. $\mathrm{br} /$ index.html?method=mostrarlnstitucional\&id=7\&idioma=ingles

ABIPET (2019) $11^{\circ}$ Census of PET Recycling in Brazil. https://blogdoplastico.wordpress.com/2020/06/17/abipet-divulga-dados-do110-censo-da-reciclagem-do-pet-no-brasil/

Alfaia, R. G. de S. M.; Costa, A. M.; Campos, J. C.; Waste Manag Res $35,1195-1209$

DOI: $10.1177 / 0734242 \times 17735375$

ANCAT -Associação Nacional de Catadores de Materiais Recicláveis (2019) Anuário da Reciclagem 2017-2018. ANCAT/Pragma/LCA. www.mncr.org.br

ANCAT- Associação Nacional de Catadores de Materiais Recicláveis (2020) LR Database. https://www.recicla.eco.br/ (last accessed in 18 May 2020)

Atasu,A. (2018) Operational Perspectives on Extended Producer Responsibility. Journal of Industrial Ecology Volume 23, Number 4.

Batista, L.; Gong, Y.; Pereira, S.; Jia, F.; Bittar, A. (2018) Circular supply chains in emerging economies- a comparative study of packaging recovery ecosystems in China and Brazil. International Journal of Production Research, 57:23, 7248-7268, DOI: 10.1080/00207543.2018.1558295

Brouillat, E.\& Oltra, V. (2012) Extended producer responsibility instruments and innovation in eco-design: An exploration through a simulation model. Ecological Economics V.83, 236-245.

Burcea, Ş.G. (2015) The Economical, Social and Environmental Implications of Informal Waste Collection and Recycling. Theoretical and Empirical Researches in Urban Management Volume 10 Issue 3 / August 2015.
Cahill, R., Grimes, S. M., \& Wilson, D. C. (2011) Extended producer responsibility for packaging wastes and WEEE-a comparison of implementation and the role of local authorities across Europe. Waste Management \& Research, 29(5), 455-479.

CEMPRE (2018), Relatório Técnico:Acordo Setorial de Embalagens em Geral, Relatório Final Fase (Technical Report: Packaging Sectorial Agreement, Phase I - in Portuguese), by Lenum Ambiental/CEMPRE. https://www.coalizaoembalagens.com.br/

Černiauskaite, I. (2013) Waste Management Reform and Revision of Packaging and Packaging Waste EPR System :The Case of Finland. Thesis (M.Sc). Lunds University.

Chen,F., Luo, Z., Yang, Y, Liu, Gang-Jun and J Ma, J.(2018) Enhancing municipal solid waste recycling through reorganizing waste pickers: A case study in Nanjing, China. Waste Management \& Research 2018, Vol. 36(9) 767-778 DOI: 10.1177/0734242X18766216

Da Cruz, N. F.; Simões, P.; Marques, R. C. (2014) Costs and benefits of packaging waste recycling systems. Resources, Conservation \& Recycling, April 2014, Vol.85, pp.1-4.2014.

Da Cruz, N. F.; Ferreira, S.; Cabral, M.; Simões, P.; Marques, R.C. (2014) Packaging waste recycling in Europe: Is the industry paying for it? Waste Management, February 2014, Vol.34(2), pp.298-308. 2014.

DANONE ECOSYSTEM. (2016) DANONE ECOSYSTEM: Handbook of Inclusive Economy, Recycling and Packaging Cycles in Action, 2016, www.ecosystem.com

Demajorovic, J. ; Massote, B. (2017)Sectoral agreement on packaging: Assessment based on extended producer responsibility/Acordo Setorial de Embalagem: Avaliação a Luz da Responsabilidade Estendida do Produtor/Acuerdo sectorial de envases: Evaluacion a la luz de la responsabilidad extendida del productor. RAE 2017, Vol.57(5), p.470(13).(in Portuguese)

Demajorovic, J.; Caires, E.F; Gonçalves, L.N.da S.; Silva, M.J. da C. (2014) Integrando empresas e cooperativas de catadores em fluxos reversos de resíduos sólidos pós-consumo: o caso Vira-Lata (Interconnecting companies and waste picker cooperatives in reverse flows of post-consumer solid waste: the "Vira-Lata" case). Cad. EBAPE.BR, v. 12, Edição Especial, artigo 7, Rio de Janeiro, Ago. 2014.

Dias, S. (2016) Waste pickers and cities. Environment \& Urbanization Vol 28(2): 375-390. International Institute for Environment and Development (IIED). DOI: 10.1177/0956247816657302

EASAC - the European Academies' Science Advisory Council (2020) Packaging plastics in the circular economy. www.easac.eu

EEA - European Environment Agency (2005) Effectiveness of packaging waste management systems in selected countries: an EEA pilot study. EEA Report No 3/2005. EEA, Copenhagen 2005. http:// europa.eu.int.

EC-DGEnv- European Commission - DG Environment (2014), Development of Guidance on Extended Producer Responsibility (EPR)-FINAL REPORT, by BIO by Deloitte in collaboration with Arcadis, Ecologic, Institute for European Environmental Policy (IEEP), Umweltbundesamt (UBA). https://ec.europa.eu/environment/archives/waste/eu_guidance/index.html

EC-DGEnv- European Commission - DG Environment (2012), Use of Economic Instruments and Waste Management Performances - Final Report, by BIO Intelligence Service. https://ec.europa.eu/ environment/waste/pdf/final_report_10042012.pdf

Ellen MacArthur Foundation (2013). Towards the Circular Economy. https://www.ellenmacarthurfoundation.org/publications/ towards-the-circular-economy

Ellen MacAthur Foundation (2013a), Towards the Circular Economy Opportunities for the consumer goods sector, https:// www.ellenmacarthurfoundation.org/publications/towards-the-circular-economy-vol-2-opportunities-for-the-consumer-goods-sector

EU (2018) DIRECTIVE (EU) 2018/852 OF THE EUROPEAN PARLIAMENT AND OF THE COUNCIL of 30 May 2018 amending Directive 94/62/EC on packaging and packaging waste. https://eur-lex.europa.eu/legal-content/EN/TXT/?qid=1529413058624\&uri=CELEX:32018L0852

EU (2018a) DIRECTIVE (EU) 2018/852 OF THE EUROPEAN PARLIAMENT AND OF THE COUNCIL of 30 May 2018 amending Directive 199/31/EC on the landfill of waste. https://eur-lex.europa. eu/legal-content/EN/TXT/?qid=1529413058624\&uri=CELEX:32018L0850

EU (2018b) DIRECTIVE (EU) 2018/852 OF THE EUROPEAN PARLIAMENT AND OF THE COUNCIL of 30 May 2018 amending Directive 2008/98/EC on waste. https://eur-lex.europa.eu/legal-content/ EN/TXT/?qid=1529413058624\&uri=CELEX:32018L0851 
EUROPEN - The European Organization for the Packaging and the Environment (2014), Extended Producer Responsibility (EPR) for used Packaging - FACTSHEET, Brussels, www.europen-packaging.eu

EUROSTAT (2019) Packaging waste by waste management operations and waste flow. https://ec.europa.eu/eurostat/web/products-datasets/-/ENV_WASPAC

Ezeah, C. Fazakerley, J.A.; Roberts, C.L.(2013) 'Emerging trending in Informal Sector Recycling in developing and Transitions Countries'. Waste Management 33: 2509-2519.

Fernandes, A.G. (2016) Closing the loop - The benefits of the circular economy for developing countries and emerging economies. Tearfund 2016. www. tearfund.org

Ferronato, N.; Rada, E. C.; Gorritty Portillo, M. A.; Cioca, L. I.; Ragazzi, M.; Torretta, V. (2019) Introduction of the circular economy within developing regions: A comparative analysis of advantages and opportunities for waste valorization. Journal of Environmental Management 230 (2019) 366-378.

Flick,U. (2004) Uma introdução à Pesquisa Qualitativa (Introduction to Qualitatite Research). Porto Alegre: Bookman, 2004.

Forslind KH. (2009) Does the financing of extended producer responsibility influence economic growth? Journal of Cleaner Production 17:297-302.

Grant, M.J. \& Booth,A. (2009) A typology of reviews: an analysis of 14 review types and associated methodologies. Health Information and Libraries Journal,26, pp.91-108. DOI: 10.1111/j.14711842.2009.00848.x

GiZ GmbH (2018) Extended Producer Responsibility (EPR) for Managing Packaging Waste. Circular Economy Briefing Series. Deutsche Gesellschaft für Internationale Zusammenarbeit (GIZ) $\mathrm{GmbH}$ www.giz.de

GiZ GmbH (2018a) Inclusion of informal collectors into the evolving waste management system in Serbia- A roadmap for integration. Climate Sensitive Waste Management (DKTI), Project

"Municipal Waste and Wastewater Management - IMPACT" in Serbian municipalities in 2016 - 2017. www.giz.de

Giovannini, M.\&Huybrechts, B. (2017) How inclusive is inclusive recycling? Recyclers' perspectives on a cross-sector partnership in Santiago de Chile. Local Environment, 2017, Vol.22 (12), p.14971510

Gonçalves-Dias, S. L. F; Teodósio, A. S. S. Estrutura da cadeia reversa: "caminhos" e "descaminhos" da embalagem PET. Produção, v. 16, n. 3, p. 429-441, 2006

Gui,L.; Atasu, A;Ergun,O.;Beril Toktay,L. (2016) Efficient Implementation of Collective Extended Producer Responsibility Legislation. Management Science. Vol. 62, No. 4, April 2016, pp. 1098-1123.

Gunsilius, E., Spies, S., García-Cortés, S., Medina, M., Dias, S., Scheinberg, A., Sabry, W., Abdel-Hady, N., Florisbela dos Santos, A.L., Ruiz, S. (2011). Recovering resources, creating opportunities. Integrating the informal sector into solid waste management, retrieved from: http://www.giz.de/de/downloads/giz2011-en-recycling-partnerships-informal-sector-final-report.pdf.

Gupt, Y.; Sahay, S. (2015) Review of extended producer responsibility: A case study approach. Waste Management \& Research, July 2015 Vol.33(7), pp.595-611.

Gutberlet, J. (2015) Cooperative urban mining in Brazil: Collective practices in selective household waste collection and recycling. Waste Management 45:22-31 http://dx.doi.org/10.1016/j.wasman.2015.06.023

Gutberlet, J. (2009) Solidarity economy and recycling co-ops: micro-credit to alleviate poverty. Develop. Pract. 19 (6), 737-751.

Gutberlet, J. (2008). Empowering collective recycling initiatives: Video documentation and action research with a recycling co-op in Brazil. Resources, Conservation \& Recycling, 52, 659-670.

Hogg, D.; Elliott,T.; Burgess,R.; Vergunst,T. (2018) Study to Identify Member States at Risk of Non-Compliance with the 2020 Targe of the Waste Framework Directive and to Follow-up Phase 1 and 2 of the Compliance Promotion Exercise - Final Report. Report for the European Commission, DG Environment, Waste Management and Secondary Materials Unit. Eunomia Research \& Consulting. Bristol/UK.

Hotta, Y.; Hayashi,S.; Bengtsson,M.;Mori,H.(2009) Resource Efficiency and EPR in East Asia (report). Institute for Global Environmental Strategies.Japan.

Hoornweg,D. and Bhada-Tata, P. (2012) WHAT A WASTE A Global Review of Solid Waste Management. World Bank. Washington, DC 20433 USA. www.worldbank.org/urban
Hwang, B.B., (2007) Unpacking the Packaging Problem: An International Solution for the Environmental Impacts of Packaging Waste. University of Baltimore. June, 2007. https://works.bepress.com/ billy_hwang/1/

IBGE, Instituto Brasileiro de Geografia e Estatística (2015) Indicadores de Desenvolvimento Sustentável, Brasil; IBGE: Rio de Janeiro, Brazil, 2015. Available online: http://www.ibge.gov.br/home/geociencias/recursosnaturais/

ids/default_2015.shtm (accessed on 15 June 2017)

INSEA - Instituto Nenuca de Desenvolvimento Sustentável (2018) Database Programa Novo Ciclo (confidential - authorized access for the research). Data parcially publisehd also on AVINA, Fundação (2019) RECICLAGEM INCLUSIVA - Relatório de Atividades do Programa Novo Ciclo 2012 2019. www.avina.net

IRR - Iniciativa Regional para el Reciclaje Inclusivo (2018) Estudio comparativo de legislación y políticas públicas de Responsabilidad Extendida del Productor - REP para empaques y envases, www. reciclajeinclusivo.org. (In Spanish)

IRR - Iniciativa Regional para el Reciclaje Inclusivo (2018a) La implantación del sistema de

Logística Inversa en Brasil y la participación de los recicladores de materiales en ella. IRR/ANCAT. www.reciclajeinclusivo.org. (In Spanish)

Jaligot R. Wilson D.C. Wilson, Cheeseman C.R., Shakerb, B., Stretzb J.(2016) Applying value chain analysis to informal sector recycling: A case study of the Zabaleen. Resources, Conservation and Recycling 114 (2016) 80-91. http://dx.doi.org/10.1016/j.resconrec.2016.07.006

King,M.F; Gutbelert,J.(2013) Contribution of cooperative sector recycling to greenhouse gas emissions reduction: A case study of Ribeirão Pires, Brazil. Waste Management 33 (2013) 2771-2780. http://dx.doi.org/10.1016/j.wasman.2013.07.031

Lenkiewicz Z. (2016) Waste and the Sustainable Development Goals. https://wasteaid.org/waste-sustainable-development-goals/

Lerpiniere,D.\& Cook,E. (2018) Improving Markets for Recycled Plastics - Trends, Prospects and Policy Responses. OECD. www.oecd-ilibrary.org. http://dx.doi.org/10.1787/9789264301016-en.

Lifset, R., Atasu,A. And Tojo,N.(2013).Extended Producer Responsibility. Journal of Industrial Ecology 17(2)p.162-166

Lima, F.P.A.; Varella, C.V.S.; Oliveira, F.G.; Parreira, G.; Rutkowski, J.E. Tecnologias Sociais da Reciclagem: Efetivando Políticas de Coleta Seletiva com Catadores. In Gerais: Revista Interinstitucional de Psicologia, 4 (2), Ed. Especial; UFMG: Belo Horizonte, Brazil, 2011; pp. 131-146

Lindhqvist, T., \& Lifset, R.(1998) Getting the goal right: EPR and DfE. Journal of Industrial Ecology, 2(1), 6-8

Massarutto, A. (2014) The long and winding road to resource efficiency - An interdisciplinary perspective on extended producer responsibility. Resources, Conservation and Recycling,Volume 85, April 2014, Pages 11-21.

Mayers,C.K.(2007) Strategic, Financial, and Design Implications of Extended Producer Responsibility in Europe: A Producer Case Study. Journal of Industrial Ecology Volume 11, Number 3.

Mayers,K. \& Butler, S. (2013) Producer Responsibility Organizations Development and Operations: A Case Study. Journal of Industrial Ecology Volume 17, Number 2. DOI: $10.1111 /$ jiec. 12021

Medina M. (2007) The world's scavengers: salvaging for sustainable consumption and production. Lanham: AltaMira Press.

Medina, M. (2000). Scavenger Cooperatives in Asia and Latin America. Resources, Conservation and Recycling, 31(31), pp. 51-69.

Michaelis, P. (1995) Product stewardship, waste minimization and economic efficiency: lessons from Germany. Journal of Environmental Planning and Management, 38(2), 231-244.

Mrkajić, V.; Stanisavljevic, N.; Wang, X.; Tomas, L.; Haro, P. (2018) Efficiency of packaging waste management in a European Union candidate country. Resources, Conservation \& Recycling, September 2018, Vol.136, pp.130-141

Nahman,A. (2010) Extended producer responsibility for packaging waste in South Africa: Current approaches and lessons learned. Resources, Conservation and Recycling 54 (2010) 155-162.

OECD - ORGANISATION FOR ECONOMIC CO-OPERATION AND DEVELOPMENT (2016), Extended Producer Responsibility: Updated Guidance for Efficient Waste Management, OECD Publishing, Paris, https://doi.org/10.1787/9789264256385-en.

OECD - ORGANISATION FOR ECONOMIC CO-OPERATION AND DEVELOPMENT (2001) EPR- A Guidance for Governments. OECD Publications Service, Paris. 
PNRS- Brazilian Solid Waste Act( Politica Nacional de Resíduos Sólidos in Portuguese)- Lei 12.305/ 2010. http://www.planalto.gov.br/ ccivil_03/_ato2007-2010/2010/lei/l12305.htm

PPWD-European Parliament and Council Directive 94/62/EC of 20 December 1994 on Packaging and Packaging Waste. (1994) Official Journal L 365, 31/12/1994, pp. 0010 - 0023. https://ec.europa.eu/ environment/waste/packaging/legis.htm

Purshouse H., Rutkowski J.E., Velis C., Rutkowski E., Estevam, V. S., Soares, A., Waste Sorting Social Technology in Brazilian Informal Materials Recovery Facilities (2017). CEST 2017- 15th International Conference on Environmental Science and Technology, Rhodes, Greece, 31 August to 2 September 2017.

Rogoff, M.J.; Ross, D.E. (2016). The future of recycling in the United States. Waste Management \& Research.Vol.34(3). pp.181-183. DOI 1177/07342422X16629599

Rutkowski, J.E and Rutkowski, E.W. (2017) Recycling in Brasil: Paper and Plastic Supply Chain. Resources 2017, 6, 43; doi:10.3390/resources6030043. 2017.

Rutkowski, J.E. \& Rutkowski E.W. (2015) Expanding worldwide urban solid waste recycling: The Brazilian social technology in waste pickers inclusion. Waste Management \& Research 33(12):108493. DOI: $10.1177 / 0734242 \times 15607424$

Rutkowski,J.E (2013) Redes solidárias de catadores e gestão de resíduos sólidos (Solidarity networks of waste pickers and waste management) Revista Tecnologia e Sociedade, Edição Especial V Simpósio de Tecnologia e Sociedade - 2013. n. 1 (out. 2005). Curitiba: Editora UTFPR/Editora CEFET-PR. ISSN (versão online): 1984-3526.

Rutkowski, J. E. (2008) Sustainability of Solidarity Economic Enterprises: an approach in Production Engineering. Thesis (DSc in Production Engineering). COPPE, Rio de Janeiro/ RJ: Universidade Federal do Rio de Janeiro, Brazil 2008. 239f. (In Portuguese).

Sapuric, Z., Shkrijelj, S., Josifovski, B. (2017) Informal sector inclusion in the sustainable waste management system as an opportunity for employment and social inclusion of vulnerable groups. Project "FISCAST. UK Government. The British Embassy Skopje/Macedonia (www.financethink.mk/.../01/InformalSector_Waste_Final_ EN.pdf)

Scharff,C.(2018) The EU Circular Economy Package and the Circular Economy Coalition for Europe. Circular Economy Coalition for Europe. www.cec4europe.eu/

Scheinberg, A., Nesic, J., Savain, R., Luppi, P., Sinnott, P., Petean, F., Pop F. (2016) From collision to collaboration - Integrating informal recyclers and reuse operators in Europe: a review. Waste Management\& Rese-arch 2016, Vol.34 (9)820-839. DOI:10.1177/0734242X16657608

Scheinberg, A.; Simpson, M. (2015) A tale of five cities: Using recycling frameworks to analyse inclusive recycling performance. Waste Management \& Research 2015, Vol. 33(11) 975-985 DOI: $10.1177 / 0734242 \times 15600050$

Scheinberg A (2012) Informal sector integration and high perfomance recycling: Evidence from 20 cities. WIEGO Working Paper (Urban Policies), no. 23. Manchester, UK, 2012.

Scheinberg, A. ; Wilson, D. C. and Rodic, L. (2010) "Solid Waste Management in the World's Cities," 3rd Edition, UN-Habitat's State of Water and Sanitation in the World's Cities Series, Earthscan for UN-Habitat, London and Washington DC, 2010.

Scheinberg A, Simpson M, Gupt Y. (2010) Economic Aspects of the Informal Sector in Solid Waste Management. WASTE, SKAT, and city partners for GTZ (Deutsche Gesellschaft fu“ r Technische Zusammenarbeit) and CWG (Collaborative Working Group on Solid Waste Management in Low- and Middle-Income Countries) Eschborn, Germany.

Schumacher, E. F. (1973) Small Is Beautiful: Economics as if People Mattered: 25 Years Later...With Commentaries. Hartley \& Marks Publishers ISBN 0-88179-169-5

Sembiring E \&Nitivattananon V (2010) Sustainable solid waste management toward an inclusive society: integration of the informal sector. Resources Conservation \& Recycling 54(11): 802-809.
Silpa,K.; Yao,L.;Bhada-Tata,P. and Van Woerden, F. (2018) What a Waste 2.0: A Global Snapshot of Solid Waste Management to 2050. International Bank for Reconstruction and Development / The World Bank, Washington, 2018. https://openknowledge.worldbank.org/ handle/10986/2174.

SNIS - Brazilian System for Information on Sanitation (in Portuguese) (2018) $17^{\circ}$ Diagnóstico do Manejo de Resíduos Sólidos Urbanos. Ministério de Desenvolvimento Regional/ Secretaria Nacional de Saneamento. http://www.snis.gov.br/diagnosticos

Tearfund, Fauna \& Flora International (FFI), WasteAid and The Institute of Development Studies (IDS) (2019) NO TIME TO WASTE- Tackling the plastic pollution crisis before it's too late. Tearfund. http:// www.learn.tearfund.org

Thiollent, M. (2011). Action Research and Participatory Research: An Overview. International Journal of Action Research, 7(2), 160-174. https://nbn-resolving.org/urn:nbn:de:0168-ssoar-414079

Tojo, N;Lindhqvist, T.; Davis, G.A., (2001) OECD Seminar on Extended Producer Responsibility, EPR Programme Implementation: Institutional And Structural Factors, OECD, 2001.

UN-Habitat (2010) WATER AND SANITATION IN THE WORLD'S CITIES, Earthscan Publications, London, http://www.waste.nl/sites/ waste.nl/files/product/files/swm_in_world_cities_2010.pdf

Valor Econômico (2011) Análise setorial-Resíduos sólidos: Logística Reversa. In Estrutura, Mercado, Perspectivas; Valor Econômico: São Paulo, Brazil, 2011; p. 140

Velis, C.A., Wilson, D.C., Rocca, O., Smith, S.R., Mavropoulos, A. \& Cheeseman, C.R. (2012) 'An analytical framework and tool ('InteRa') for integrating the informal recycling sector in waste and resource management systems in developing countries', Waste Management \& Research, 30(9 Suppl), pp. 43-66.

Walls M. (2006) Extended producer responsibility and product design, economic theory and selected case studies. In: Resources for the future, Discussion paper 06-08-2006. https://www.rff.org/publications/working-papers/extended-producer-responsibility-and-product-design-economic-theory-and-selected-case-studies/

WRAP (2015) WRAP. Plastics Compositional Analysis at MRFs Final Report. Project code: IMT003-109 Research: February-June 2014 Publication: January 2015. http://www.wrap.org.uk/content/sorting-materials-materials-recovery-facilities-mrfs

WRAP (2006) WRAP Materials Recovery Facilities - MRFs Comparison of efficiency and quality. The Dougherty Group LLC/WRAP. September 2006. http://www.wrap.org.uk/content/sorting-materials-materials-recovery-facilities-mrfs

WFD Waste framework directive, 2008/98 EC European Parliament and Council Directive 98/EC of 20 December 1998 on Waste Framework Directive (1998) Official Journal of the European Union L 150/109, 14/06/2018. https://www.eea.europa.eu/policy-documents/waste-framework-directive-2008-98-ec

Wiesmeth, H. ; Shavgulidze, N. ; Tevzadze, N.(2018) Environmental policies for drinks packaging in Georgia: A mini-review of EPR policies with a focus on incentive compatibility. Waste Management \& Research, November 2018, Vol.36(11), pp.1004-1015

Wiesmeth, H. \&Häckl, D. (2011) How to successfully implement extended producer responsibility: considerations from an economic point of view. Waste Management \& Research, September 2011, Vol.29(9), pp.891-901

Wilson, D.C., Velis, C., \& Rodic, L.(2013) Integrated sustainable waste management in developing countries. Waste and Resource Management 166,May 2013, Issue WR2, Pages 52-68 http://dx.doi. org/10.1680/warm.12.00005

Wilson, DC, Rodic, L, Scheinberg, A. (2012) Comparative analysis of solid waste management in 20 cities. Waste Management \& Research 30: 237-254.

Wilson, D.C., Velis, C., \& Cheeseman, C. (2006). Role of informal sector recycling in waste management in developing countries. Habitat International, 30(4),797-808.

World Bank, NOTE NO. 44 (2008) by Martin Medina, The informal recycling sector in developing countries Organizing waste pickers to enhance their impact, Grid Lines Publishing, www.ppiaf.org/ gridlines. 